Article

\title{
Hydrogeological Behaviour and Geochemical Features of Waters in Evaporite-Bearing Low-Permeability Successions: A Case Study in Southern Sicily, Italy
}

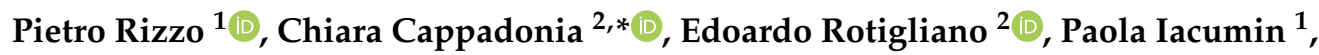 \\ Anna Maria Sanangelantoni ${ }^{1}$, Giulia Zerbini ${ }^{1}$ and Fulvio Celico ${ }^{1}$ \\ 1 Department of Chemistry, Life Sciences and Environmental Sustainability, University of Parma, Parco Area \\ delle Scienze 157/A, 43124 Parma, Italy; pietro.rizzo@unipr.it (P.R.); paola.iacumin@unipr.it (P.I.); \\ annamaria.sanangelantoni@unipr.it (A.M.S.); giulia.zerbini@studenti.unipr.it (G.Z.); \\ fulvio.celico@unipr.it (F.C.) \\ 2 Department of Earth and Marine Sciences, University of Palermo, Via Archirafi 22, 90123 Palermo, Italy; \\ edoardo.rotigliano@unipa.it \\ * Correspondence: chiara.cappadonia@unipa.it; Tel.: +39-091-2386-4664
}

Received: 4 September 2020; Accepted: 17 November 2020; Published: 18 November 2020

check for updates

Featured Application: The research suggests an approach for refining the guidelines to be used in studying heterogeneous media and planning optimal monitoring networks and protocols for several anthropogenic purposes (e.g., environmental monitoring of landfills or contaminated sites managing).

\begin{abstract}
Knowledge about the hydrogeological behaviour of heterogeneous low-permeability media is an important tool when designing anthropogenic works (e.g., landfills) that could potentially have negative impacts on the environment and on people's health. The knowledge about the biogeochemical processes in these media could prevent "false positives" when studying groundwater quality and possible contamination caused by anthropogenic activities. In this research, we firstly refined knowledge about the groundwater flow field at a representative site where the groundwater flows within an evaporite-bearing low-permeability succession. Hydraulic measurements and tritium analyses demonstrated the coexistence of relatively brief to very prolonged groundwater pathways. The groundwater is recharged by local precipitation, as demonstrated by stable isotopes investigations. However, relatively deep groundwater is clearly linked to very high tritium content rainwater precipitated during the 1950s and 1960s. The deuterium content of some groundwater samples showed unusual values, explained by the interactions between the groundwater and certain gases $\left(\mathrm{H}_{2} \mathrm{~S}\right.$ and $\left.\mathrm{CH}_{4}\right)$, the presences of which are linked to sulfate-reducing bacteria and methanogenic archaea detected within the saturated medium through biomolecular investigations in the shallow organic reach clayey deposits. In a wider, methodological context, the present study demonstrates that interdisciplinary approaches provide better knowledge about the behaviour of heterogeneous low-permeability media and the meaning of each data type.
\end{abstract}

Keywords: conceptual model; evaporites; bacterial community; stable isotopes; tritium; Southern Italy

\section{Introduction}

The Mediterranean region was affected by a pervasive "salinity crisis" during the Messinian, when it was progressively restricted and partially isolated from the Atlantic Ocean by a combination 
of tectonic and glacio-eustatic processes [1-4] that resulted in the deposition of large volumes of evaporitic sediments [5,6]. The Messinian Sicilian Basins are very important geologic systems for analysing these evaporite successions, in view of their lateral variations and subsequent deformation [7]. Their syn-tectonic evolution is in fact fundamental to reconstructing the timing and geometry of the propagating thrust belt $[8,9]$. In particular, progressive filling of sub-basins led to the formation of aquifer systems characterised by the coexistence of very low permeability clay successions and evaporitic lenses/horizons [10]. From a hydrochemical point of view, both low- and high-salinity groundwaters may be found associated with the mineralogical features described above.

Several hydrogeological and geochemical studies have been carried out in such settings. Some of these studies provided preliminary characterisations through the analysis of single sampling campaigns [11-13], whereas others investigated in greater detail the hydrogeological behaviour and the hydrochemical evolution over time based on more prolonged and multidisciplinary approaches [14-16]. Worldwide, a variety of conceptual models have been proposed for groundwater circulation in evaporite deposits. In some systems, the hydrogeology and hydrochemistry of the evaporitic aquifers are significantly influenced by deep ascending regional fluids [17-20]; conversely, at other sites, the hydrogeology and hydrochemistry of the studied system are influenced by the mixing of saline groundwater (flowing through evaporitic rocks) with more diluted waters flowing through nearby porous aquifers [21], with the possible influence of surface waters [22,23] or peat layers [24].

The main objective of this study was to refine knowledge about the hydrogeological behaviour of such systems. Because of the expected complexity, the study was carried out by merging hydraulic head measurements, isotopic analyses, and microbial community investigations, as to acquire a broad spectrum of complementary hydraulic and biogeochemical information.

The hydraulic head measurements were carried out to analyse the groundwater flow field from a three-dimensional perspective and investigate the existence of possible vertical flow components influencing the groundwater pathways and residence times.

The isotopic analyses were conducted to refine knowledge about the groundwater origins (stable isotopes of oxygen and deuterium) and residence times (tritium). Isotopes, together with chemical features, are among the major groundwater tracers traditionally and widely employed in hydrogeological studies (e.g., [25-29]).

The microbial community investigations were performed to analyse the isotopic signatures of the groundwater from a biogeochemical perspective, as to avoid incorrect interpretations of geochemical data. Microbial communities are influenced by the physicochemical features of the environment in which they live and are excellent investigative tools in several hydrogeological scenarios. The efficacy of using microorganisms for specific hydrogeological purposes has been verified in several settings that are partially comparable with that addressed in this study, such as karstified media (e.g., [30,31]), low-permeability media (e.g., [32,33]), and high-salinity groundwaters (e.g., [34]).

The usefulness and the efficacy of a coupled isotopic-microbiological approach has been verified in other complex hydrogeological settings (e.g., [35]), taking into consideration how microorganisms migrate in the subsurface (e.g., [36]).

Taking into consideration the key items highlighted in previous papers, this study was devoted mainly to examining in depth the role of certain hydraulic heterogeneities in influencing the groundwater flow field, as well as the role of microbial communities in influencing the isotopic signature of groundwater. Based on this goal, and according to the successful results of former studies performed at the same scale in similar setting [14-16], this first step of the research was carried out within a relatively narrow experimental site (in the order of $1 \mathrm{~km}^{2}$ ). In fact, minimising the extension of the study site at this stage, allowed to minimise the distance between investigation boreholes and wells, and maximise the opportunity to understand the heterogeneity degree of the studied system from the geological, hydrogeological and biogeochemical points of view. 


\section{Study Area}

The study area is located in south-western Sicily, between the small towns of Siculiana and Montallegro (Figure 1). It geologically corresponds (Figure 2a; [37]) to the south to southeast-vergent Sicilian Fold and Thrust Belt (FTB, [38]) bordered by the Gela thrust front and Kabilian-Calabrian thrust front. The FTB is an element of the collisional complex of Sicily, which also includes a late Pliocene-Quaternary foredeep (Gela foredeep), onlapping the frontal sector of the thrust belt in the southern part of the island, its offshore area, and the Pelagian-Iblean foreland with its African crust. In particular, the southern and central parts of the FTB (Figure 2b), are characterised by the outcropping of the most complete evaporitic succession of the "Gessoso-Solfifera" formation of the Messinian age [39].

The evaporitic deposits (Figure 3) mainly consist of limestone, gypsum, salt, and numerous intercalations of clays, marls, and carbonates. Gypsum strata are composed of various kinds of selenite (branching, banded, and massive) and detrital gypsum layers alternating with marl and carbonate. The Messinian units overlie diatomitic laminites (Tripoli formation [Fm.]: TRP) and clay deposits of late Tortonian to Early Messinian age, and the succession is overlain by Pliocene marly calcilutites (Trubi Fm.: TRB). The whole sequence [41] is locally overlain by middle-upper Pliocene marly clays (Monte Narbone Fm.: NRB). Sandy clays and arenites (Montallegro Fm.: MNT), clays breccias (BRC), and turbiditic calcarenites (Agrigento Fm.: GRG) are the more recent Pleistocene units.

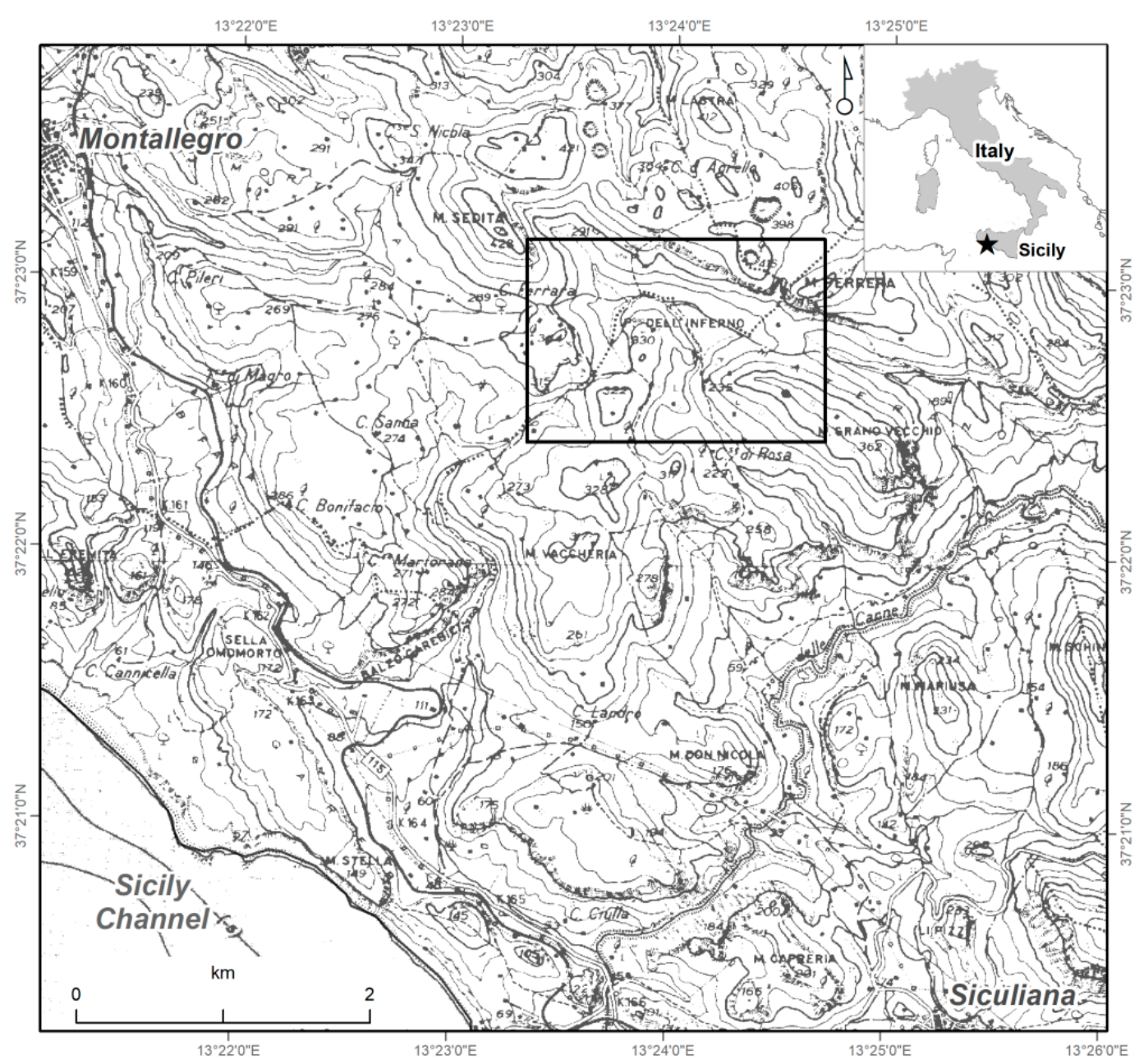

Figure 1. Geographic setting and general map of the study area. 


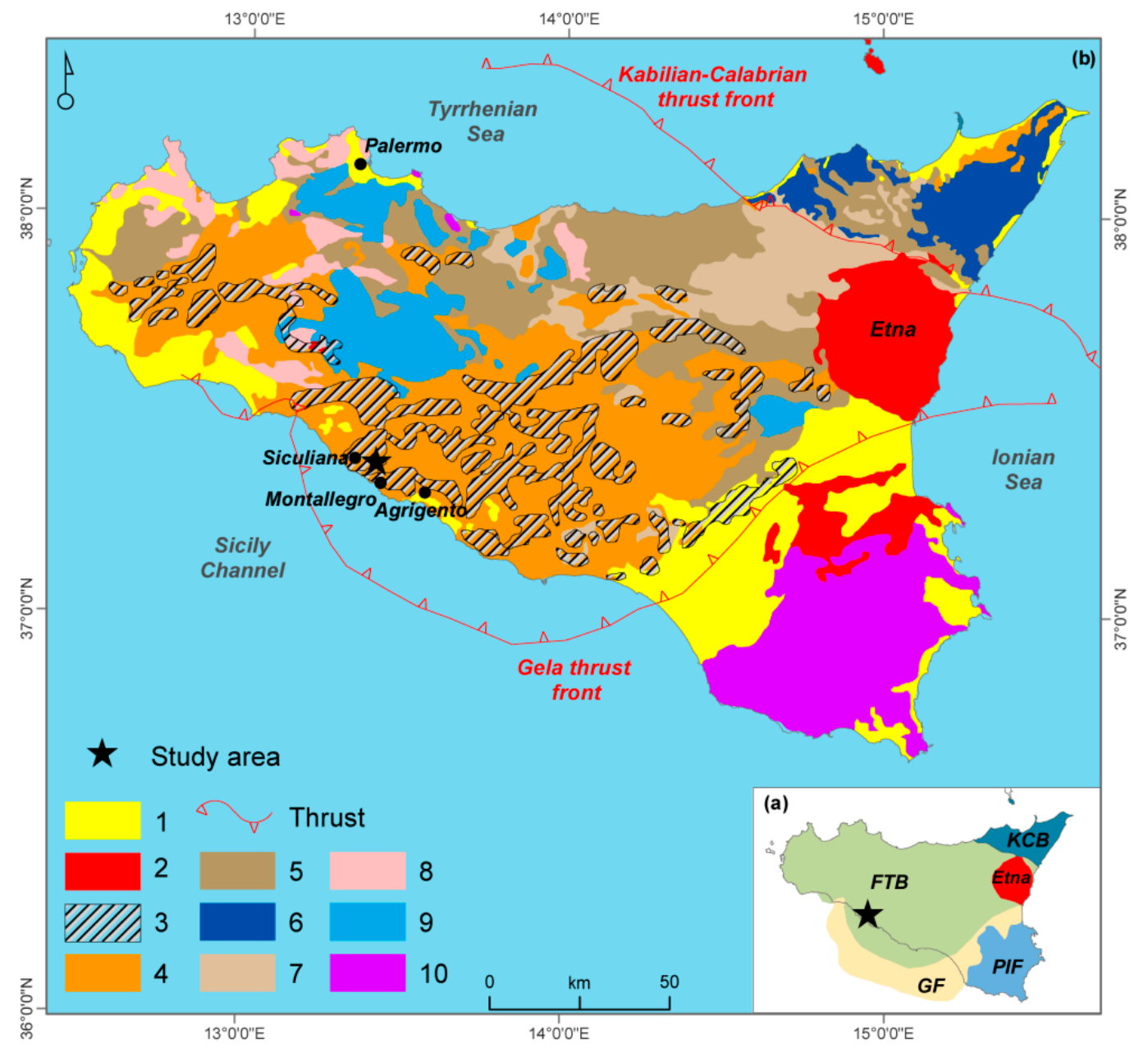

Figure 2. (a) Mt. Etna edifice and main elements of the collisional complex of Sicily: Kabylian-Calabrian thrust basement—KCB; fold and thrust belt_FTB; Gela foredeep—GF; Pelagian-Iblean foreland-PIF; (b) structural map of Sicily (modified from [40]) highlighting the spatial distribution of the evaporite outcrops in Sicily (after [39]): (1) Plio-Pleistocene cover, (2) volcanics, (3) evaporites (Messinian), (4) upper Miocene-lower Pliocene deformed foreland deposits, (5) upper Oligocene-lower Miocene deformed foreland deposits, (6) Kabilian-Calabrian crystalline units, (7) Sicilide units, (8) Meso-Cenozoic carbonate platform deformed units (Sicilian-Maghrebian shallow-water units), (9) Meso-Cenozoic slope-to-deep-basin deformed units (Sicilian-Maghrebian deep-water units), and (10) Meso-Cenozoic carbonate platform not-deformed units (Sicilian-Maghrebian foreland).

In greater detail, a first and a second sedimentary cycle [42] are distinguished in the Messinian evaporites, which are separated by an angular unconformity. The first cycle comprises [43]: carbonate deposits (Calcare di Base Fm.: BEC), massive selenite (Cattolica Fm.: CTL), and a salt unit (Clastic Ca-sulfates, Mg and $\mathrm{K}$ salts, and halite unit: SLT). The younger second cycle is mainly characterised by thin gypsum layers (balatino and selenite: GPQ) and marls layers (upper evaporites, Pasquasia Fm.: GPQ) levels interbedded with detrital mud, silt, sandstones, and conglomerates overlain by siliciclastic sediments (mainly silty clays; Arenazzolo Fm.: RNZ), characterised by marked organic matter levels.

The complexity of the geological setting of the area is increased to be a consequence of the Plio-Pleistocene tectonic phases that generated the fold and thrust belts and high-angle faults with subsequent lateral contacts between the Messinian gypsum units and the older clayey deposits. In addition, the wide distribution of soluble rocks in this sector of Sicily is responsible for intense karstic processes, producing a great variety of either epigeous and hypogeous landforms [41]. 


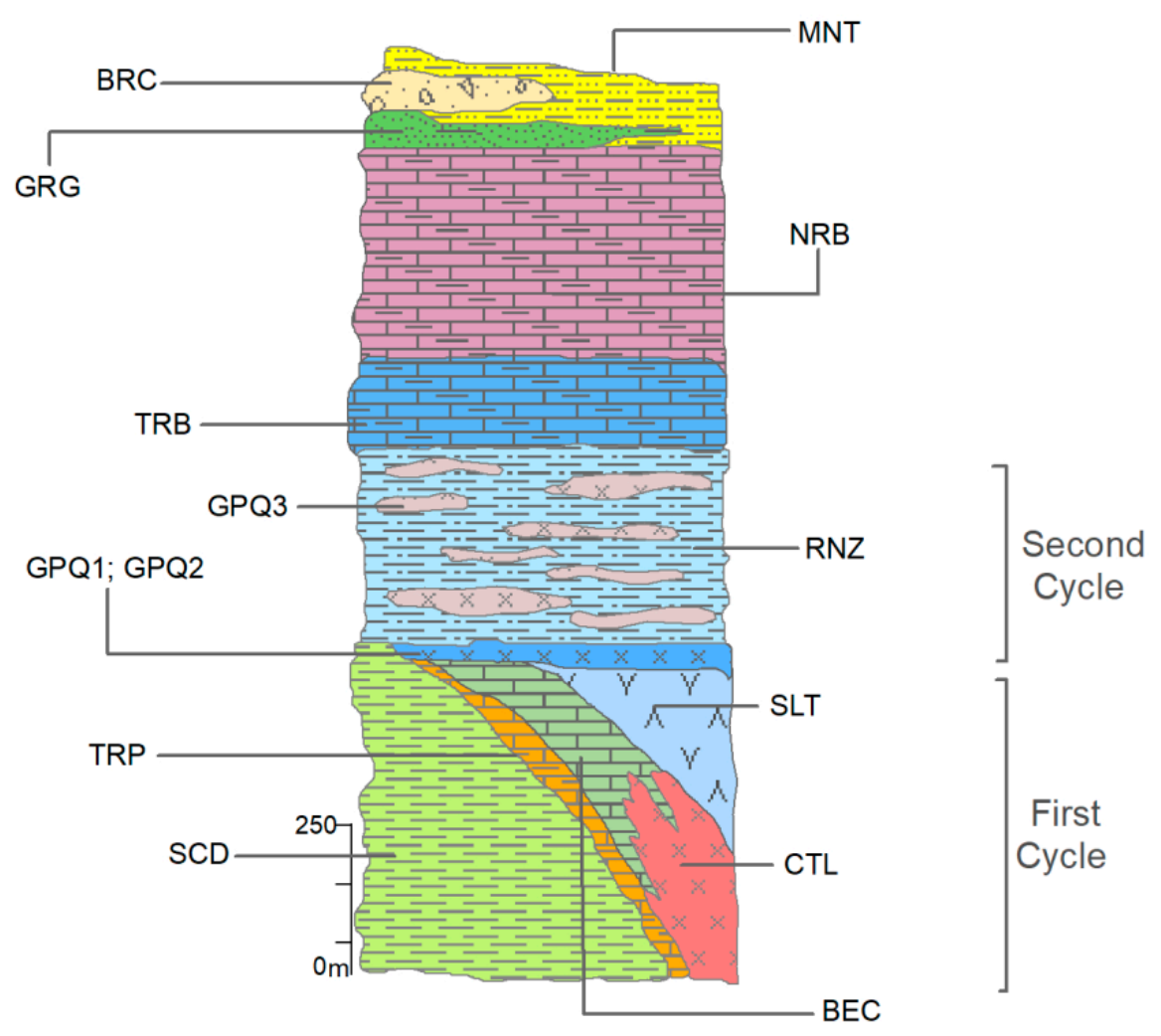

Figure 3. Schematic stratigraphic sequence of the evaporites in south-western Sicily (after [44]): clayey deposits (SCD—Tortonian-middle Serravallian); Messinian evaporites—first cycle: white diatomitic marls, Tripoli Fm. (TRP-Messinian); carbonate breccias and clastic gypsum, Calcare di Base Fm. (BEC-Messinian); massive selenite, Cattolica Fm. (CTL-Messinian); clastic Ca-sulfates, Mg- and K-salts, and halite unit, forming a salt unit (SLT-Messinian); second cycle: gypsum-arenites and limestones and carbonate arenites, Pasquasia Fm. (GPQ1; GPQ2-Messinian); gypsum (balatino and selenite) and marls, Pasquasia Fm. (GPQ3-Messinian); Siliciclastic sediments rich in organic matter, Arenazzolo Fm. (RNZ-Messinian); marly calcilutites, Trubi Fm. (TRB-Early Pliocene); marls, marly clays, sandy clays, Monte Narbone Fm. (NRB-middle-upper Pliocene); yellow sands and lagoonal sandy-clays, Montallegro Fm. (MNT-lower Pleistocene); turbiditic calcarenites, Agrigento Fm. (GRG-lower Pleistocene); clay breccias (BRC-lower Pleistocene).

From a morpho-structural standpoint, the landscape is characterised by a system of gentle anticlines and synclines extending parallel to the NW-SE trend of the FTB and large blocks of evaporitic rocks encircled by clayey deposits, with frequent relief inversion produced by differential erosion phenomena [39]. The folded relief is also intersected by perpendicular faults connecting different parts of the evaporites bodies and/or clayey deposits. The area is characterised by a series of slightly sloped fluvial terraces, frequently cut in their upper parts by long gullies and V-shaped valleys. Karst processes have affected gypsum areas, resulting in a great variety of surface landforms, such as poljes, karren, and gypsum bubbles. On the clayey slopes, morphogenetic processes produced landforms such as shallow landslides, rills, and gullies [45].

Following the above-mentioned general geological setting, in the study area, the Mio-Pliocene deposits consisting of an evaporite series and pre-evaporite strata are involved in a wide range of fold structures on a NNW-SSE axis and are capped by weakly deformed Pleistocene deposits and Quaternary terrains. The shapes of the structures are irregular fashion because of the different stratigraphic thicknesses of the evaporitic rocks, which were also controlled by active thrust and fold structures at the time of deposition [7] and by the significant competence contrasts between various formations described in Figure 3, such as coarse-grained gypsum, muds, silty clays, and silts. In general, the evaporitic deposits of the second cycle (gypsum and marls; GPQ1; GPQ2 and GPQ3) locally overlie 
the massive selenites of the CTL (first cycle) and the SCD with an erosional unconformity, and are in turn overlain by the silty clays of the RNZ.

To reconstruct the local geology, the stratigraphic logs of 18 geognostic boreholes and 22 piezometers were taken into consideration, and a geological map (Figure 4) was constructed, which is marked by the outcropping of several components of the whole succession. Based on the available stratigraphic data, two interpretative profiles extending E-W and N-S were also drawn (Figure 5).

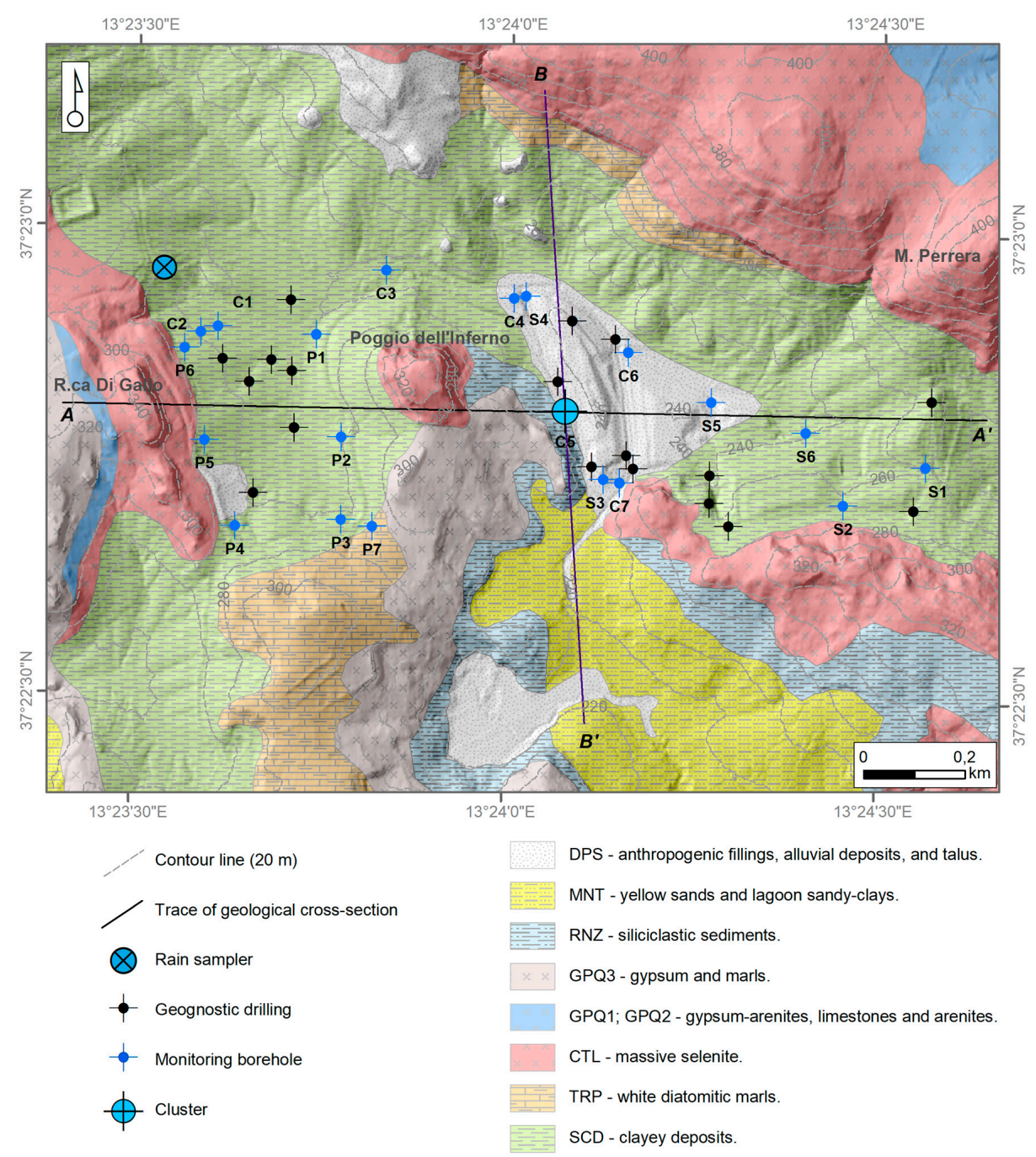

Figure 4. Geological map of the study area and location of the geognostic and monitoring boreholes.

The two profiles depict the general expected setting of the area, with a folded regular sequence marked by first cycle (CTL) gypsum layers overlaying the diatomites (TRP) levels or directly in contact on the Tortonian clayey deposits (SCD). The second cycle evaporitic layers (GPQ1, GPQ2, GPQ3, and RNZ) cover in sequence the CTL only along the north-south profile, and elsewhere directly overlie the SCD. At the base, the whole area is characterised by the continuous thick Tortonian clayey layer (SCD). In the southern flank of the anticline, a thick sandy/sandy-clayey (MNT) layer outcrops, covering the RNZ. In the central sector of the study area, along the main drainage surficial line, the evaporitic terrains are covered by a large patch of mainly alluvial quaternary deposits and characterised by high organic matter content. 

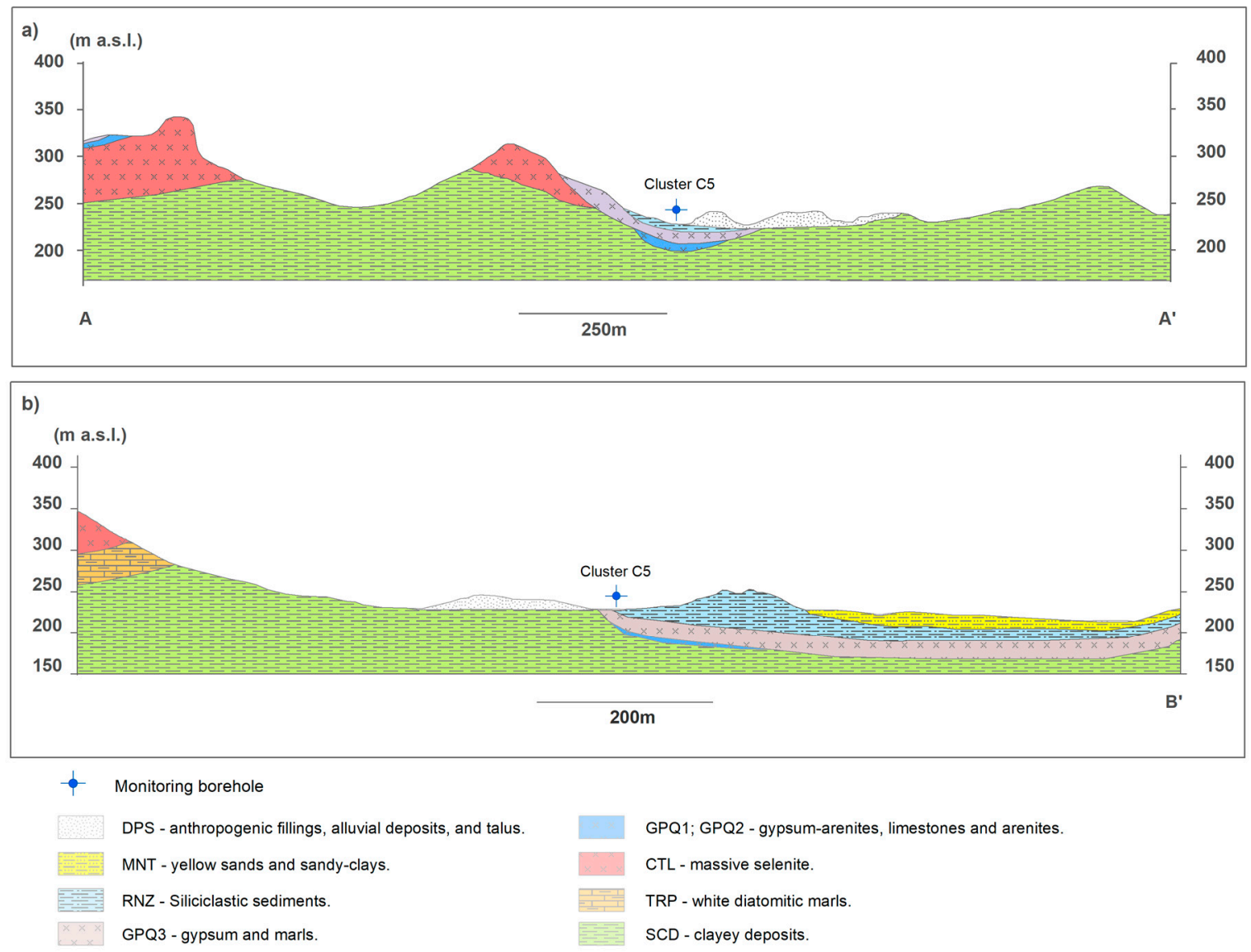

GPQ1; GPQ2 - gypsum-arenites, limestones and arenites.

CTL - massive selenite.

TRP - white diatomitic marls

SCD - clayey deposits.

Figure 5. Geological cross-sections (see Figure 4 for traces).

\section{Materials and Methods}

An interdisciplinary approach was employed in order to analyse the groundwater flow field and the hydrogeological behavior of the studied system from a three-dimensional perspective. The possible influence of vertical flow on groundwater pathways and residence times was explored by merging hydrogeological and isotopic investigations. Microbial community analyses were conducted to investigate the isotopic signature of the groundwater from a biogeochemical perspective, to ensure that the results of the isotopic analyses were correctly interpreted, with emphasis on the deuterium content.

Graphic images were obtained using QGIS, Adobe Illustrator and Microsoft Excel.

\subsection{Hydrogeological Investigations}

From May 2011 to November 2019, the hydraulic head at the piezometers was measured on a weekly to monthly basis using a water level meter to reconstruct the groundwater flow net and its evolution over time. To specifically investigate the vertical zonation of the hydraulic head and the isotopic/microbiological features within the heterogeneous medium, one multilevel groundwater monitoring system (cluster type) was drilled in August 2019: the C5 cluster (Figure 6), which included three piezometers screened at different depths ( $\mathrm{C} 5 \mathrm{a}, \mathrm{C} 5 \mathrm{~b}$, and $\mathrm{C} 5 \mathrm{c})$. The $\mathrm{C} 5$ cluster was drilled close to a former and abandoned piezometer (30 $\mathrm{m}$ deep and fully screened), in which the sampled groundwater was characterised by high tritium content (36.5 tritium units [T.U.]), to also deeply investigate the origin of this apparent anomaly. The other piezometers ranged in depth between 15 and $40 \mathrm{~m}$, depending on the local depth of the groundwater head. 


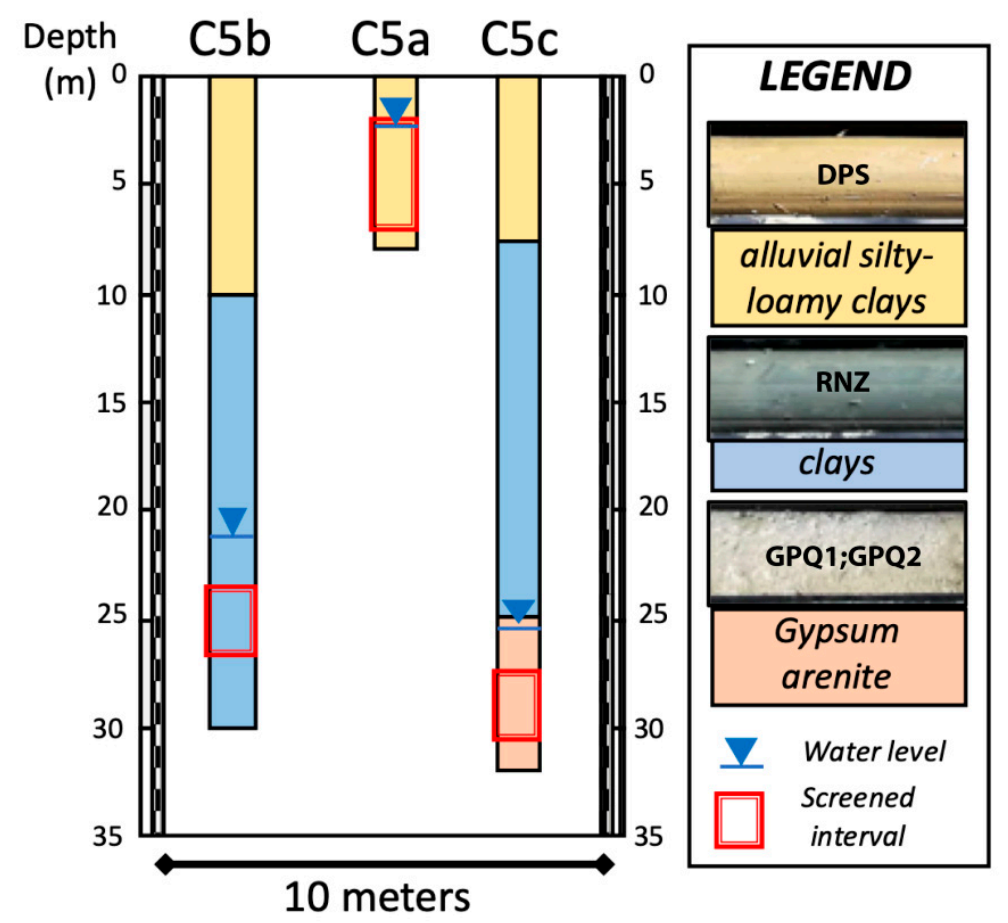

Figure 6. Cluster C5: stratigraphy, screened intervals, and water levels in December 2019. DPS-anthropogenic fillings, alluvial deposits, and talus (Quaternary); RNZ-siliciclastic sediments with high organic matter content, Arenazzolo Fm. (Messinian); GPQ1 and GPQ2-gypsum-arenites and limestones and carbonate arenites, Pasquasia Fm. (Messinian).

\subsection{Isotopic Investigations}

Groundwater samples for stable isotope $\left(\delta^{18 / 16} \mathrm{O}\right.$ and $\left.\delta^{2 / 1} \mathrm{H}\right)$ and tritium $\left({ }^{3} \mathrm{H}\right)$ analyses were collected four times (January, June, September and December 2019), together with the hydraulic head measurements. During the same observation period, rainwater samples for $\delta\left({ }^{18 / 16} \mathrm{O}\right), \delta\left({ }^{2 / 1} \mathrm{H}\right)$ and tritium analyses were collected monthly (depending on the amount of precipitation) from one rain sampler installed at the test site (Figure 4). The rainfall was collected using ten-liter polyethylene bottles containing about $300 \mathrm{~mL}$ of Vaseline oil to prevent evaporation. Oil contamination was carefully avoided by syringing the water samples out of the bottles. All the samples were transported to the laboratory in a refrigerated box.

Stable isotope analyses were carried out at the Isotope Geochemistry Laboratory of the University of Parma, Italy, using a water equilibrator at $18{ }^{\circ} \mathrm{C}$ equipped with a Finnigan Delta XP spectrometer. For oxygen isotope determination, $5 \mathrm{~cm}^{3}$ of water was equilibrated with pure $\mathrm{CO}_{2}$, whereas for hydrogen isotopes, $5 \mathrm{~cm}^{3}$ of water was equilibrated with pure $\mathrm{H}_{2}$ (platinum wire was used as a catalyser of gas-liquid water equilibration). The isotope ratio is expressed as:

$$
{ }^{\mathrm{A} / \mathrm{B}} \delta_{i / \mathrm{RF}}=\frac{\mathrm{A} / \mathrm{B} R_{i}}{\mathrm{~A} / \mathrm{B} R_{\mathrm{RF}}}-1=\left[\left(\frac{\mathrm{A} / \mathrm{B} R_{i}}{\mathrm{~A} / \mathrm{B} R_{\mathrm{RF}}}-1\right) 10^{3}\right] \%
$$

where $\mathrm{A}$ is ${ }^{18} \mathrm{O}$ or ${ }^{2} \mathrm{H}, \mathrm{B}$ is ${ }^{16} \mathrm{O}$ or ${ }^{1} \mathrm{H}, R$ is the ratio of the isotopic abundances, $i$ the sample of interest, $\%=10^{-3}$, and RF is the primary international standard of reference (in our case VSMOW-SLAP). The analyses of ${ }^{3} \mathrm{H}$ were carried out at the Isotope Geochemistry Laboratory of the University of Trieste, Italy. Following other authors (e.g., [46]), the samples followed the procedure of the preventive electrolytic enrichment of tritium was applied to the samples to decrease measurement errors. In this process, the $250 \mathrm{~g}$ of the water sample was expected to be reduced to $20 \mathrm{~g}$ by electrolysis.

The analyses for the determination of the tritium activity were carried out according to the procedures provided by the International Atomic Energy Agency [47]. 
The analytical prediction uncertainty was $\pm 0.1 \%$ o for $\delta^{18} \mathrm{O}, \pm 1 \%$ o for $\delta^{2} \mathrm{H}$, and \pm 0.5 T.U. for ${ }^{3} \mathrm{H}$.

\subsection{Microbiological Analyses: 16S Ribosomal RNA Gene Next Generation Sequencing (NGS)}

The microbiological survey was carried out in December 2019 on samples from the multilevel piezometers $\mathrm{C} 5 \mathrm{a}-\mathrm{c}$ to refine knowledge about the bacterial community in the groundwater. This survey was limited to cluster $\mathrm{C} 5$ because it was carried out to investigate the possible influence of microbial activity on some isotopic features, with emphasis on deuterium content in the $\mathrm{C} 5$ groundwater.

Water samples $(1 \mathrm{~L})$ were filtered through sterile mixed esters of cellulose filters $\left(\mathrm{S}-\mathrm{Pak}^{\mathrm{TM}}\right.$ membrane filters, $47 \mathrm{~mm}$ diameter, $0.22 \mu \mathrm{m}$ pore size, Millipore Corporation, Billerica, MA, USA) within $24 \mathrm{~h}$ after collection. Bacterial DNA extraction from the sample filters was performed using the commercial kit FastDNA SPIN Kit for soil and the FastPrep ${ }^{\circledR}$ Instrument. Once the DNA extraction was complete, the quantity and integrity of the DNA were evaluated by electrophoresis in $0.8 \%$ agarose gel, containing $1 \mu \mathrm{g} / \mathrm{mL}$ of Gel-Red ${ }^{\mathrm{TM}}$, in the running buffer TAE $1 \mathrm{X}$ ( $40 \mathrm{mM}$ tris base, $20 \mathrm{mM}$ acetic acid, and $1 \mathrm{mM}$ EDTA $\mathrm{pH} 8$ ), and amplification reactions were performed by polymerase chain reaction (PCR). The $16 \mathrm{~S}$ rDNA profiles of the bacterial communities in the samples were obtained by NGS technologies at the Genprobio Srl Laboratory (Parma, Italy). Partial 16S rRNA gene sequences were obtained from the extracted DNA by PCR, using the primer pair Probio_Uni and/Probio_Rev, which targets the V3 region of the bacterial 16S rRNA gene sequence [48], and the primer pair ArchV46 for archaeal $16 \mathrm{~S}$ rRNA [49]. Amplifications were carried out using a Verity Thermocycler (Applied Biosystems Foster City, CA, USA), and PCR products were purified by the magnetic purification using Agencourt AMPure XP DNA Purification Beads (Beckman Coulter Genomics GmbH, Bernried, Germany) to remove primer dimers. Amplicon checks were carried out as previously described [48]. Sequencing was performed using an Illumina MiSeq sequencer with MiSeq Reagent Kit v3 chemicals. The fastq files were processed using a custom script based on the QIIME software suite [50]. Quality control retained sequences with lengths between 140 and $400 \mathrm{bp}$ and mean sequence quality scores $>20$, whereas sequences with homopolymers $>7 \mathrm{bp}$ and mismatched primers were omitted. To calculate downstream diversity measures, operational taxonomic units (OTUs) were defined at $100 \%$ sequence homology using DADA2 [51]; OTUs not encompassing at least two sequences of the same sample were removed. All reads were classified to the lowest possible taxonomic rank using QIIME2 [50,52] and a reference dataset from the SILVA database v132 [53]

\section{Results and Discussion}

\subsection{Hydrogeological Features}

The hydraulic head fluctuated over the year from tens of centimeters to several meters, depending on the area. A recession period was typically observed from late spring to early autumn, whereas recharge was typically observed from early autumn to spring (Figure 7). Overall, the head measurements suggested relatively slow recharge, according to the low bulk permeability of the studied system, which does not favor rapid percolation of fresh-infiltration waters within the unsaturated zone and corresponding short-term fluctuations of the groundwater surface. The low bulk permeability of the studied medium is in agreement with the findings of other authors who performed pumping tests in similar Messinian successions in Southern Italy (transmissivity on the order of $10^{-5} \mathrm{~m}^{2} / \mathrm{s} ;[14,16]$ ).

Based on the hydrogeological monitoring and survey results, the general groundwater flow scheme in the area was reconstructed (Figure $8 \mathrm{a}$ ). The groundwater flows from the highlands towards the topographic depressions, with the hydraulic gradient ranging from $\sim 30 \%$ to $\sim 3 \%$, respectively. The lowest head was consistently measured within the eastern depression, in the area of piezometers S3-S5, and no significant modifications of the groundwater flow net were observed over time, during the observation period. Therefore, all the piezometers used to analyse the isotopic signature from a hydrogeological perspective maintained the same hydraulic relationships throughout the year. 
This finding implies that all the results discussed in the isotopic section were not influenced at all by modifications of the groundwater flow field.

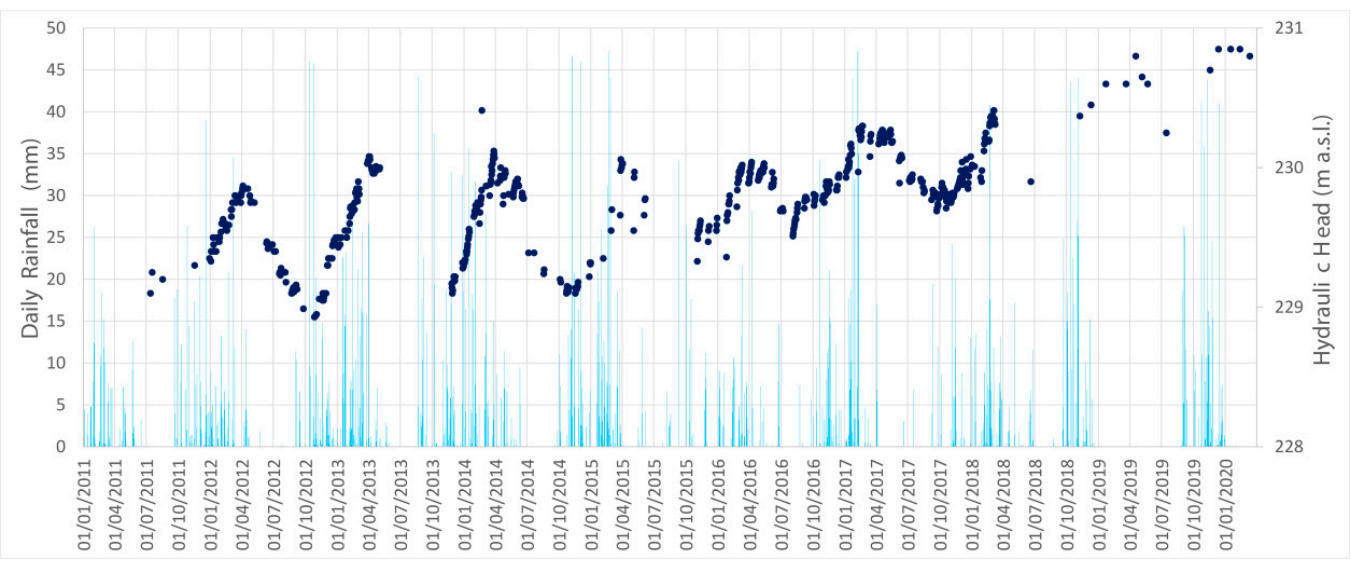

Figure 7. Hydraulic head variations in piezometer S4 (blue dots) vs. daily rainfall (light blue bars). Dates are given in day/month/year format.
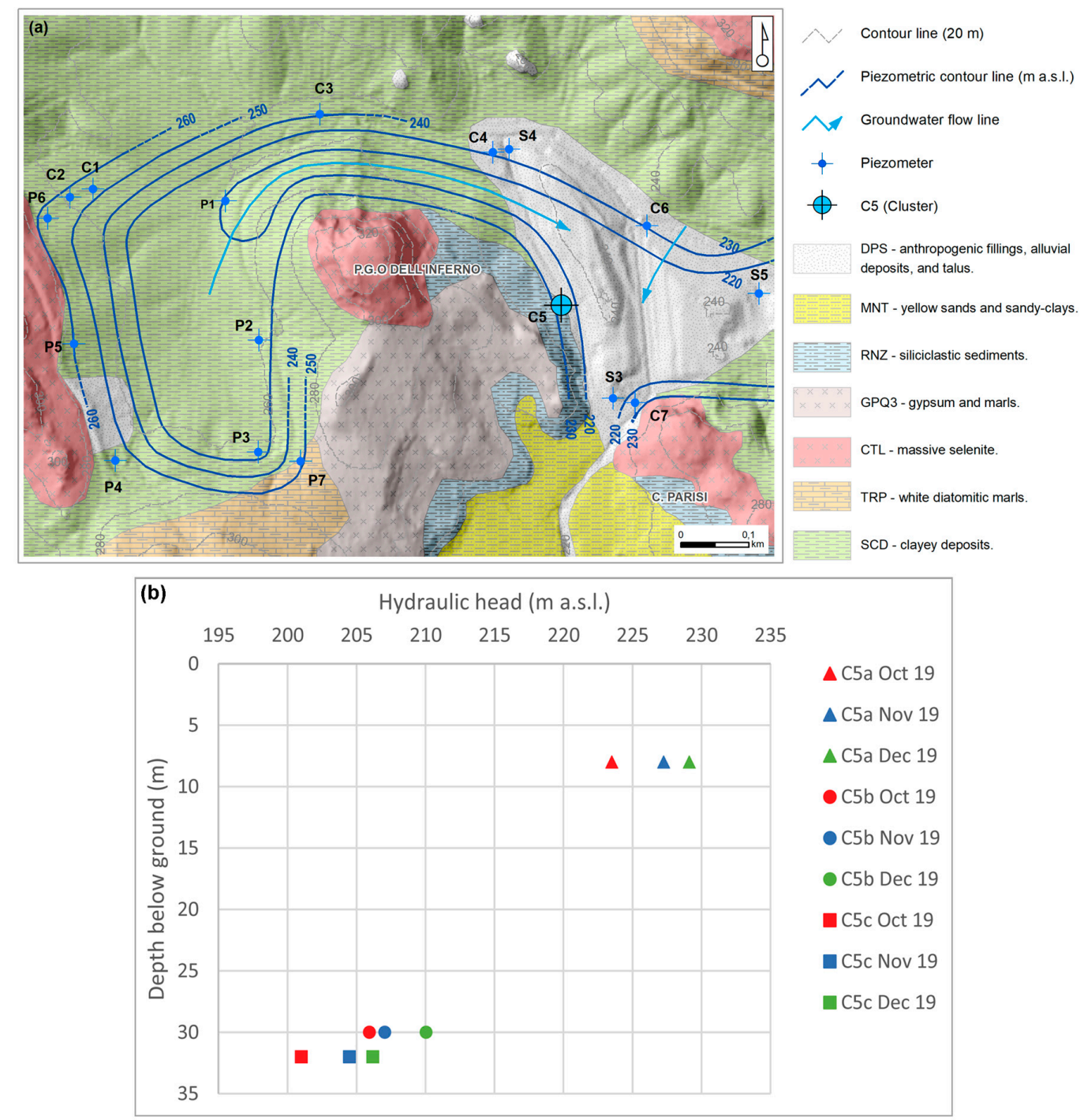

Figure 8. (a) Hydrogeological map of the study area (December 2019); (b) relationship between the hydraulic head and the depth below ground observed at the C5 cluster. 
In light of the sedimentological features and common lateral inhomogeneity of the evaporitic layers (Figure 3), simple expected hydrogeological and hydrochemical behaviors are difficult to define for the sequence that outcrops at the key site of the C5 cluster. In fact, the RNZ layer, which overlies the second cycle gypsum evaporitic bodies, is composed of a very chaotic sandy-clayey deposits, including dispersed gypsum blocks; consequently, a moderate primary permeability is expected, despite the high clay content. In addition, the first cycle evaporitic layers and the basal Tortonian clays are expected to be characterised by high and low permeability, respectively, whereas the role of the second cycle gypsum bodies, which are to be classified as permeable on a small scale, could be strongly controlled, overall, by the lack of lateral continuity, resulting in very slow hydraulic circuits.

As observed at the C5 cluster, the hydraulic head significantly varied with depth (Figure 8b). In greater detail, it progressively decreased with increasing depth, showing the highest head in the shallow system and the lowest one into the piezometer $\mathrm{C} 5 \mathrm{c}$, screened within a gypsum horizon. The head zonation was confirmed based on the seasonal groundwater oscillation, with coherent hydraulic heads shifts, consistent with the fact that the analysed medium behaves as a continuum at the observation scale of the present study. This finding is also in agreement with the expectation for saturated heterogeneous media comparable with the studied media. In these media, if a lower geological formation has a higher hydraulic conductivity than the overlying layer, it acts as the major conduit of flow [54]. The highest head in C5a was compatible with the phreatic surface reconstructed within the whole studied area, the morphology of which reflects the local topography (Figure 8a), as expected in such low-permeability systems.

\subsection{Hydrogen and Oxygen Isotopes}

Waters from all the piezometers $\mathrm{P}, \mathrm{S}$, and $\mathrm{C}$ shown in Figure 8a were sampled for $\delta^{18 / 16} \mathrm{O}$ and $\delta^{2 / 1} \mathrm{H}$ measurements. The values of the analysed samples ranged from $-37.0 \%$ o to $2.2 \%$ o for hydrogen and from $-6.8 \%$ o to $-0.2 \%$ for oxygen. Three different main groups could be identified: Group A (P1, P2, $\mathrm{P} 3$ and S6) exhibited the highest $\delta^{2 / 1} \mathrm{H}$ and $\delta^{18 / 16} \mathrm{O}$ values in the intervals from $-5.2 \%$ o to $2.2 \%$ o and from $-1.1 \%$ o to $-0.2 \%$, respectively; Group B (wells P4, P5, P7, S1, S2, S3, and S5) had intermediate values in the ranges from $-16.0 \%$ o to $-10.6 \%$ or for $\delta^{2 / 1} \mathrm{H}$, and from $-3.4 \%$ o to $-2.4 \%$ o for $\delta^{18 / 16} \mathrm{O}$; Group C (wells $\mathrm{P} 6, \mathrm{~S} 4, \mathrm{C} 1, \mathrm{C} 3$, and $\mathrm{C} 4$ ) included the lowest $\delta^{2 / 1} \mathrm{H}$ and $\delta^{18 / 16} \mathrm{O}$ values, from $-26.3 \%$ o to $-20.5 \%$ o and from $-5.5 \%$ o to $-4.2 \%$, respectively (Figure 9 ). For all the piezometers, the isotopic values did not change in the different sampling periods, with the exception of $\mathrm{C} 2, \mathrm{C} 6$ and $\mathrm{C} 7$, which showed swings across groups $\mathrm{B}$ and $\mathrm{C}\left(\mathrm{C} 2: \delta^{2 / 1} \mathrm{H}=-22.9 \%\right.$ o to $-8.4 \%$ o and $\delta^{18 / 16} \mathrm{O}=-4.6 \%$ o to $-2.0 \%$; $\mathrm{C} 6: \delta^{2 / 1} \mathrm{H}=-25.0 \%$ o to $-9.8 \%$ ond $\delta^{18 / 16} \mathrm{O}=-5.1 \%$ o to $-2.3 \%$ o $\mathrm{C} 7: \delta^{2 / 1} \mathrm{H}=-37.0 \%$ o to $-24.1 \%$ o and $\delta^{18 / 16} \mathrm{O}=-6.8 \%$ o to $-5.0 \%$ o). The groundwater samples collected in the $\mathrm{C} 5$ cluster exhibited a very unusual distribution. In the $\delta^{2 / 1} \mathrm{H}$ vs. $\delta^{18 / 16} \mathrm{O}$ diagram shown in Figure 9, their $\delta^{2 / 1} \mathrm{H}$ values are distributed vertically ranging from about -23.5 to $-8.5 \%$ o (see below for more details).

Regarding the affinity of the sampled groundwaters, all groups plotted along the local meteoric water lines available in the scientific literature [55-62], being consistent with those of rainwater collected in the study area during the observation period; this finding suggests a meteoric origin for the analysed waters (Figure 9), with no influence of ascending fluids coming from deep reservoirs, the isotopic signature of which are notably different from those of actual precipitations [35].

The $\delta^{2 / 1} \mathrm{H}$ and $\delta^{18 / 16} \mathrm{O}$ values are correlated with the depth of the phreatic surface (Figure 10). The piezometers showing the deepest phreatic surface ( $>25 \mathrm{~m}$ below ground, $\mathrm{m} \mathrm{b.g.)} \mathrm{belong} \mathrm{to} \mathrm{Group}$ A; Group B includes phreatic surface at 23.5 to $17 \mathrm{~m} \mathrm{b.g.;} \mathrm{Group} \mathrm{C} \mathrm{may} \mathrm{be} \mathrm{divided} \mathrm{into} \mathrm{two} \mathrm{different}$ sub-groups: one with a depth lower than $6 \mathrm{~m} \mathrm{b.g.,} \mathrm{and} \mathrm{another} \mathrm{one} \mathrm{with} \mathrm{a} \mathrm{level} \mathrm{ranging} \mathrm{from} 14.5$ to $17 \mathrm{~m} \mathrm{b.g}$. Wells $\mathrm{C} 5 \mathrm{~b}$ and $\mathrm{C} 5 \mathrm{c}$ are excluded because their water levels are representative of the hydraulic head measured at different depths below ground and is not referable to the local phreatic surface (coinciding with the water level measured in C5a). 


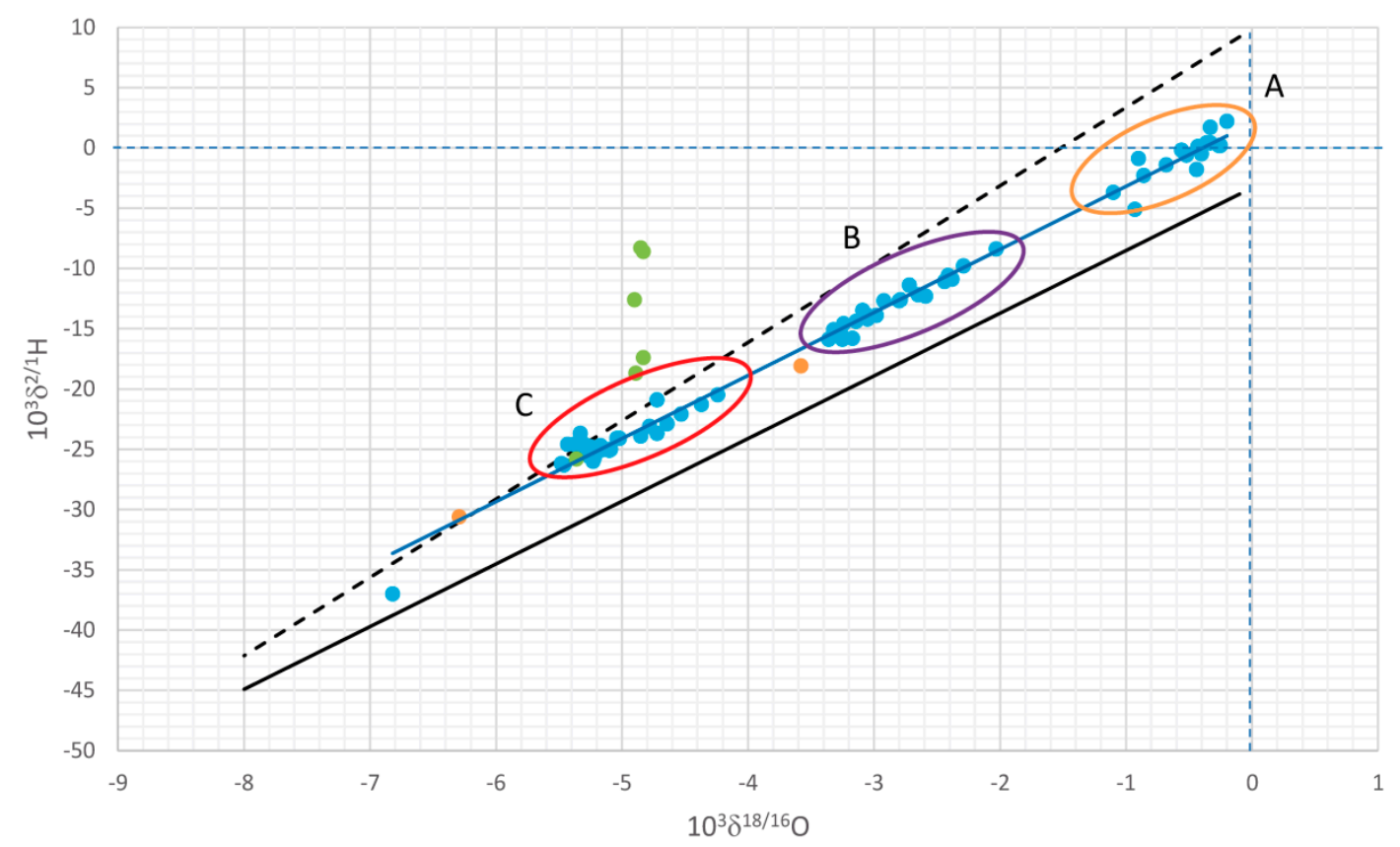

Figure 9. Relations between $10^{3} \delta^{2 / 1} \mathrm{H}$ and $10^{3} \delta^{18 / 16} \mathrm{O}$ for the investigated waters (blue dots). Groups $\mathrm{A}$, $\mathrm{B}$, and $\mathrm{C}$ are encircled in ochre, purple, and red, respectively. The green dots represent $\mathrm{C} 5 \mathrm{a}-\mathrm{C}$ waters. The orange dots indicate the rainwater samples analysed during this study. The solid black and the dashed black lines are representative of the meteoric water lines available in Sicily (with emphasis on [62] and [56], respectively). The blue line is the linear interpolation of the groundwater isotopic data.
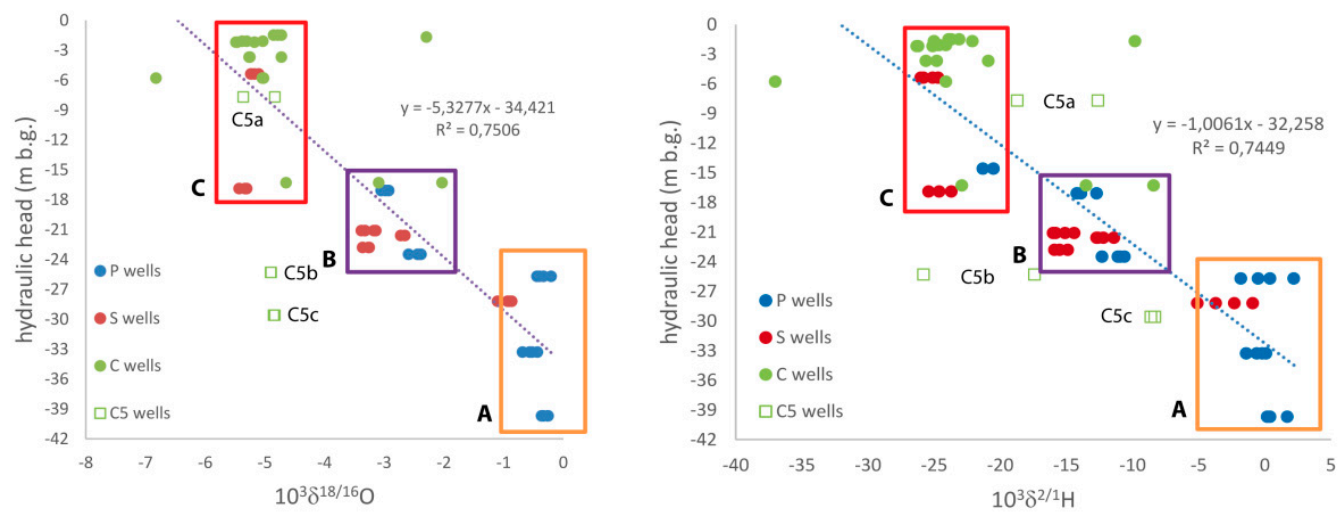

Figure 10. Relations between the hydraulic head and $10^{3} \delta^{2 / 1} \mathrm{H}$ and $10^{3} \delta^{18 / 16} \mathrm{O}$ for the investigated waters. Waters from the $\mathrm{C} 5$ cluster are not considered in the regressions.

Regarding tritium, the rainwater samples had high ${ }^{3} \mathrm{H}$ contents (6.2 to 10.8 T.U.), whereas the groundwater samples showed a wide range of tritium contents (Figure 11). Taking into consideration the tritium content detected in local rainwater during the observation period, as well as data already available for Southern Italy (e.g., 4.5 T.U. in [63]; 5.0 T.U. in [16]), three groundwater types have been detected at the study site: (i) groundwater related to rapid and/or short pathways within the aquifer system (4 to 10 T.U.), (ii) groundwater related to longer and/or prolonged pathways, with higher mean-residence times $(<4$ T.U.), (iii) groundwater related to very prolonged pathways ( $>10$ T.U., corresponding to at least 300 T.U. at the beginning of 1960s), the recharge of which, according to findings in other sites in Italy [64], is linked mainly to rainwater precipitated during the 1950s and 1960s, when tritium was spiked in the atmosphere by nuclear weapons testing [65], reaching up to several thousand T.U. in rainwater (e.g., [66]). 


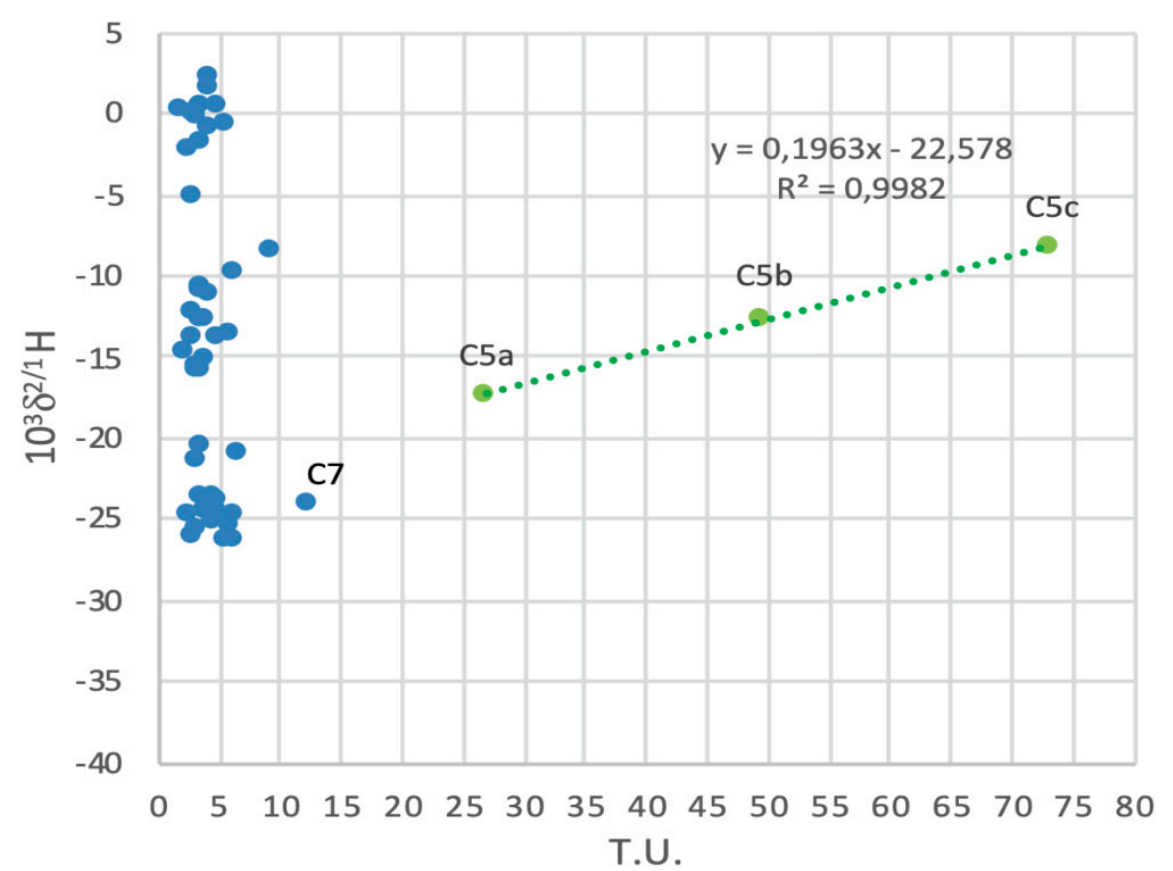

Figure 11. Relation between $10^{3} \delta^{2 / 1} \mathrm{H}$ and T.U. in the investigated waters. Waters from the C5 wells exhibit a significant $10^{3} \delta^{2 / 1} \mathrm{H}$ vs. T.U. correlation.

Figure 11 reports the relation between $10^{3} \delta^{2 / 1} \mathrm{H}$ and T.U. The evident and strongly significant correlation $\left(R^{2}=0.998\right.$, and null hypothesis $\left.\mathrm{H}_{\mathrm{o}(\mathrm{slope}=0)}<0.001\right)$ for the data of the $\mathrm{C} 5$ cluster is an intriguing problem. Different explanations for this interesting correlation are proposed below.

\subsection{Next-Generation Sequencing Results}

The microbial community of groundwater sampled in the $\mathrm{C} 5$ cluster was analysed to explore the possible influence of microbial activity $\left(\mathrm{H}_{2} \mathrm{~S}\right.$ and $\mathrm{CH}_{4}$ production) on the unusual deuterium content detected in C5-waters. The 16S rRNA gene sequences of both bacteria and archaea identified in this study have been deposited in the National Center for Biotechnology Information (NCBI) Sequence Read Archive under the accession number PRJNA631131. Based on analysis of the sequences obtained from the C 5 cluster with NGS technologies, the broad diversity of the microbial community in terms of relative abundance of bacterial genera has been highlighted (Table 1).

Regarding the main aim of the present study, the analyses showed a bacterial community characterised by aerobic and anaerobic/facultative anaerobic genera. Many of these genera are common in bacterial communities found in salty groundwater and marine environments. Halophilic bacteria can be considered moderate halophiles or extreme halophiles based on the concentration of salts present in water and soils (e.g., Alcanivorax [67] and Marinomonas [68] in Table 2); in contrast, halotolerant bacteria, despite growing better without $\mathrm{NaCl}$, can tolerate high quantities of salt [69] (e.g., Arcobacter [70] and Pseudomonas [71] in Table 2). In addition, some of the bacterial genera can exploit sulfate reduction (Desulfatiglans [72], Desulfovibrio [73], and Shewanella [74] in Table 2) as a metabolic pathway. Sulfate reduction is a form of anaerobic respiration, typical of sulfate-reducing bacteria (SRB) or sulfur-reducing bacteria, and as such typically occurs in anoxic environments and leads to the production of hydrogen sulfide $\left(\mathrm{H}_{2} \mathrm{~S}\right)$; however, some studies have found that this process can also occur in the presence of oxygen [71,75]. 
Table 1. Bacterial genera detected in groundwater samples collected in C5a-c (relative abundance $>0.7 \%$ ).

\begin{tabular}{cccc}
\hline Taxonomy & C5a & C5b & C5c \\
\hline Aeromonas & $2.13 \%$ & $0.14 \%$ & $0.07 \%$ \\
Alcanivorax & $0.72 \%$ & $0.95 \%$ & $0.46 \%$ \\
Arcobacter & $1.67 \%$ & $0.13 \%$ & $1.12 \%$ \\
Candidatus Nitrotoga & $0.00 \%$ & $0.74 \%$ & $0.33 \%$ \\
Idiomarina & $0.20 \%$ & $0.08 \%$ & $0.84 \%$ \\
Limnobacter & $1.57 \%$ & $0.00 \%$ & $2.18 \%$ \\
Magnetospira & $0.18 \%$ & $0.73 \%$ & $0.31 \%$ \\
Marinobacter & $0.11 \%$ & $0.36 \%$ & $0.98 \%$ \\
Marinobacterium & $0.05 \%$ & $0.00 \%$ & $1.29 \%$ \\
Marinomonas & $1.23 \%$ & $0.00 \%$ & $0.30 \%$ \\
Nitrosomonas & $0.00 \%$ & $3.43 \%$ & $0.64 \%$ \\
Nitrospina & $0.06 \%$ & $1.91 \%$ & $0.36 \%$ \\
Oceanobacter & $0.12 \%$ & $3.82 \%$ & $0.46 \%$ \\
Parvibaculum & $0.28 \%$ & $0.42 \%$ & $1.19 \%$ \\
Pseudohongiella & $0.85 \%$ & $2.72 \%$ & $0.85 \%$ \\
Pseudomonas & $58.95 \%$ & $52.18 \%$ & $47.22 \%$ \\
Rehaibacterium & $0.17 \%$ & $7.38 \%$ & $2.29 \%$ \\
Rheinheimera & $2.50 \%$ & $0.00 \%$ & $0.55 \%$ \\
Roseovarius & $0.04 \%$ & $0.78 \%$ & $0.30 \%$ \\
Shewanella & $7.39 \%$ & $0.07 \%$ & $0.72 \%$ \\
Sphingobium & $1.60 \%$ & $0.00 \%$ & $1.06 \%$ \\
Sphingomonas & $0.92 \%$ & $0.11 \%$ & $0.44 \%$ \\
Thiobacillus & $0.00 \%$ & $0.19 \%$ & $1.34 \%$ \\
Vibrio & $0.00 \%$ & $0.03 \%$ & $5.77 \%$ \\
\hline & & & \\
\hline & & & \\
\hline
\end{tabular}

Table 2. Metabolic characteristics of selected bacterial genera detected in groundwater samples collected in $\mathrm{C} 5 \mathrm{a}-\mathrm{c}$.

\begin{tabular}{|c|c|c|c|c|c|c|}
\hline Taxonomy & Aerobic & $\begin{array}{c}\text { Facultative } \\
\text { Aerobic }\end{array}$ & Anaerobic & $\begin{array}{l}\text { Facultative } \\
\text { Anaerobic }\end{array}$ & $\begin{array}{l}\text { Halophilic/ } \\
\text { Halotolerant }\end{array}$ & $\begin{array}{c}\text { Sulfate } \\
\text { Reduction }\end{array}$ \\
\hline Alcanivorax & + & & & & + & \\
\hline Arcobacter & & + & + & & + & \\
\hline Desulfatiglans & & + & + & & + & + \\
\hline Desulfovibrio & & + & + & & + & + \\
\hline Marinobacter & & + & & & + & \\
\hline Marinomonas & + & & & & + & \\
\hline Oceanobacter & + & & & & + & \\
\hline Pseudomonas & + & + & & & + & \\
\hline Shewanella & + & & & + & + & + \\
\hline Vibrio & + & & & + & + & \\
\hline
\end{tabular}

Regarding the archaeal component, the most abundant genus found in the analysed groundwater samples (C5a-c) was Candidatus Nitrosopumilus [76] (Table 3). This genus is typically found in marine environments where ammonia can be oxidised to nitrite. Moreover, halophilic genera were identified, such as Halococcus [77] (Table 3), a genus capable of living in the presence of very high concentrations of $\mathrm{NaCl}$ (up to $4.5 \mathrm{M} \mathrm{NaCl}$ ). Methanogenic genera, such as Methanobacterium [78], Methanimicrococcus [79], and Methanolobus [80] were also found (Table 3). Methanogenesis is a strictly anaerobic metabolic pathway that leads to the formation of methane, and s performed only by methanogenic archaea.

Thus, the biomolecular investigations demonstrated that C5-groundwaters are characterised by bacterial (Desulfatiglans, Desulfovibrio, and Shewanella) and archaeal (Methanobacterium, Methanimicrococcus, and Methanolobus) genera able to produce $\mathrm{H}_{2} \mathrm{~S}$ and $\mathrm{CH}_{4}$, respectively, therefore suggesting that microbial activity is a factor of utmost importance to be taken into consideration when analysing the isotopic signature of local groundwater. 
Table 3. Metabolic characteristics of selected archaeal genera detected in groundwater samples collected in $\mathrm{C} 5 \mathrm{a}-\mathrm{c}$.

\begin{tabular}{|c|c|c|c|c|c|c|}
\hline Taxonomy & Aerobic & Anaerobic & $\begin{array}{l}\text { Halophilic/ } \\
\text { Halotolerant }\end{array}$ & Methanogenesis & $\begin{array}{c}\text { Sulfate } \\
\text { Reduction }\end{array}$ & $\begin{array}{l}\text { Ammonia } \\
\text { Oxidizing }\end{array}$ \\
\hline Candidatus Nitrocosmicus & + & & + & & & + \\
\hline $\begin{array}{c}\text { Candidatus } \\
\text { Nitrosoarchaeum }\end{array}$ & + & & + & & & + \\
\hline $\begin{array}{l}\text { Candidatus } \\
\text { Nitrosopumilus }\end{array}$ & + & & + & & & + \\
\hline Halococcus & + & & + & & & \\
\hline Halogranum & + & & + & & + & \\
\hline Methanimicrococcus & & + & + & + & & \\
\hline Methanobacterium & & + & + & + & & \\
\hline Methanolobus & & + & + & + & & \\
\hline Methanothermobacter & & + & + & + & + & \\
\hline
\end{tabular}

\section{Hydrogeological Model}

Geological, hydrogeological, isotopic and biomolecular investigations allowed characterisation of the hydrogeological functioning of the studied heterogeneous low-permeability system, as well as refinement of knowledge about the residence time of groundwater within such systems.

As expected, taking into consideration previous studies in similar geologic settings [16], the studied system is characterised by vertical and discontinuous heterogeneity [81], caused by various factors such as (i) the coexistence of different geological formations, (ii) their folded regular sequence, and (iii) the fractured (karstified) evaporitic intrastrata/lenses that locally increase the bulk permeability of the low-permeability system. In contrast with other heterogeneous systems, no fault zones influence fluid flow, neither enhancing [82-84] nor partially or totally impeding it [85-87].

When the hydrogeological system is analysed at the basin scale, the whole system can be depicted as a continuous medium, and the groundwater flow net is a smoothed replica of the local topography. Groundwater flow clearly occurs from the highlands towards the topographic depressions.

The vertical heterogeneity of the system causes the hydraulic head to significantly vary with depth. Close to the C5a-c cluster, the hydraulic head decreases with increasing depth, with the lowest head into the karstified gypsum layer (C5c). This head distribution agrees with that observed by Petrella et al. [16] within the peninsular Southern Italy, where the more transmissive and discontinuous localised media drain the surrounding lower permeability rocks up-gradient (lower hydraulic head), whereas they are characterised by higher head down-gradient and feed the surrounding lower permeability media (Figure 12). Because the vertical heterogeneity is discontinuous, it is unable to provide a continuous solution within the stratigraphic sequence over an extended area. Therefore, in contrast with other systems characterised by vertical heterogeneity, from the hydraulic point of view [64,88-90], no perched aquifers overlie deeper ones, and a unique saturated zone can be assumed.

Overall, the heterogeneous distribution of lower- and higher-permeability rocks within the studied system, as well as the groundwater flow field described above (Figure 12), cause the mean residence time of groundwater to not necessarily be in agreement with the only groundwater flow net depicted in Figure 8. The coexistence of slower and faster flow velocities and the existence of vertical flow, cause a sort of patchwork distribution of tritium content, with higher levels detected at depths extending into evaporitic interstrata/lenses, linked mainly to rainwater precipitated during the 1950s and 1960s, when tritium was spiked in the atmosphere by nuclear weapons testing. 


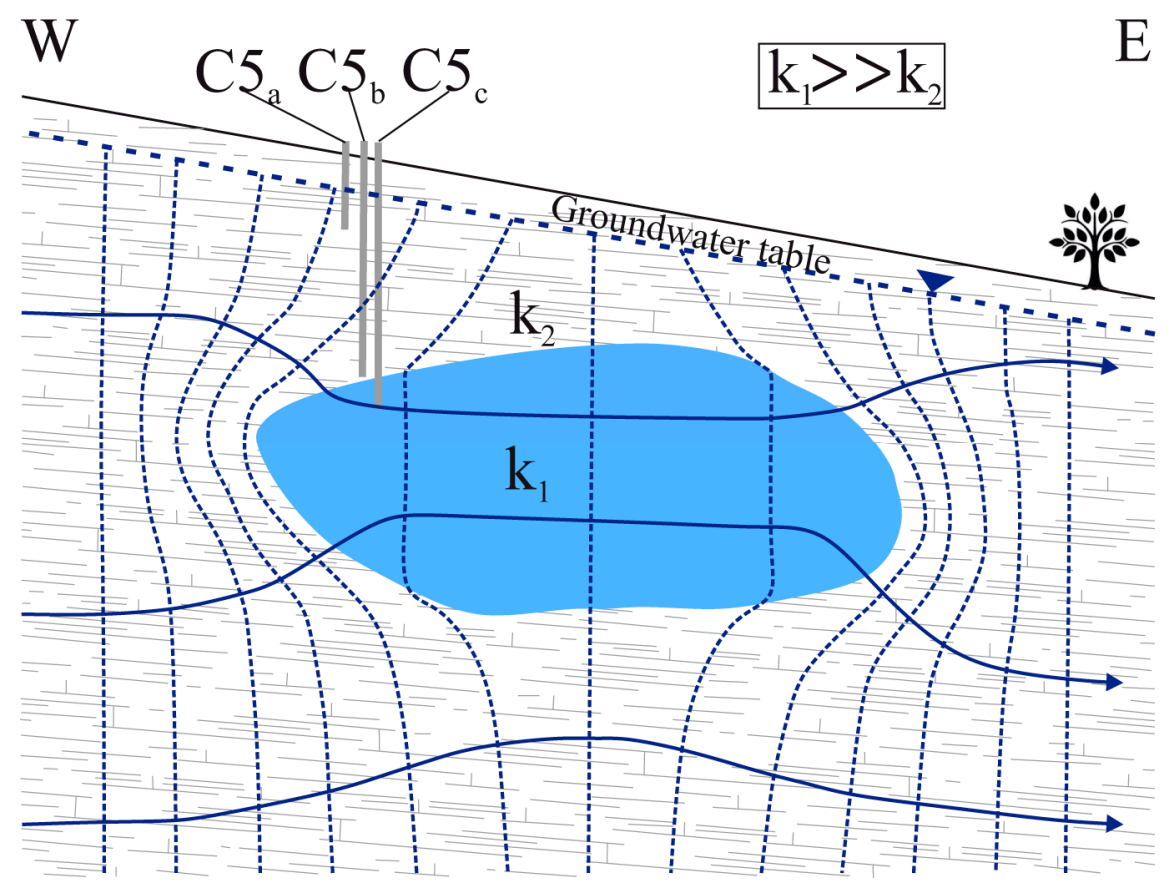

Figure 12. Conceptual hydrogeological sketch of heterogeneous media characterised by evaporite-bearing successions. The blue lens is a discontinuous evaporitic layer immersed in a clay sequence (grey). Blue dashed lines are the equipotential lines. Blue arrows are the groundwater flow lines. The C5a-c cluster is also shown. The symbols K1 and K2 are the hydraulic conductivities of the evaporitic lens and clay sequence, respectively.

The stable isotopes confirmed the local origin of the groundwater. However, as indicated above, the isotopic features of the samples coming from C5a-c cluster are unusual for groundwaters, and may be due to the phenomena discussed hereafter. Based on data reported by [91] for partitioning between liquid and gaseous water and by Galley et al. [92] for gaseous water and $\mathrm{H}_{2} \mathrm{~S}$ gas, the following approximate value for the fractionation factor of $\mathrm{H}_{2} \mathrm{O}$ liquid vs. $\mathrm{H}_{2} \mathrm{~S}$ gas at $21^{\circ} \mathrm{C}$ is obtained:

$$
{ }^{2 / 1} \alpha_{\mathrm{H}_{2} \mathrm{O}-\mathrm{H}_{2} \mathrm{~S}}=\frac{2 / 1}{{ }^{2 / 1} \delta_{\mathrm{H}_{2} \mathrm{O}+1}}=2.587 \text { at } 21{ }^{\circ} \mathrm{C}
$$

However, based on the data reported by Horibe and Craig [93], for $\mathrm{H}_{2} \mathrm{O}$ liquid vs. $\mathrm{CH}_{4}$ gas, the value:

$$
{ }^{2 / 1} \alpha_{\mathrm{H}_{2} \mathrm{O}-\mathrm{CH}_{4}}=\frac{{ }^{2 / 1} \delta_{\mathrm{H}_{2} \mathrm{O}+1}}{{ }^{2 / 1} \delta_{\mathrm{CH}_{4} \mathrm{~S}+1}}=1.283 \text { at } 21^{\circ} \mathrm{C}
$$

Thus, liquid water is strongly enriched in heavy isotopes with respect to $\mathrm{H}_{2} \mathrm{~S}$ and $\mathrm{CH}_{4}$. Based on the presence of sulfate-reducing bacteria and methanogenic archaea in the analysed C5-waters, we suggest two possible explanations for the high hydrogen isotope values: (1) interaction of water with gaseous $\mathrm{H}_{2} \mathrm{~S}$ and/or $\mathrm{CH}_{4}$ coming from the surrounding environment, and (2) generation of $\mathrm{H}_{2} \mathrm{~S}$ and $\mathrm{CH}_{4}$ by reduction of oxidised sulfur and carbon species involving the $\mathrm{H}$ component of the water (Equations (4) and (5)) [94,95]:

$$
\begin{gathered}
\mathrm{SO}_{4}^{2-}+2 \mathrm{CH}_{2} \mathrm{O} \rightarrow \mathrm{HS}^{-}+2 \mathrm{HCO}_{3}^{-}+\mathrm{H}^{\mp} \\
4 \mathrm{H}_{2}+\mathrm{HCO}_{3}^{-}+\mathrm{H}^{+} \rightarrow \mathrm{CH}_{4}+3 \mathrm{H}_{2} \mathrm{O}
\end{gathered}
$$

Here, we consider the case of continuous seepage of $\mathrm{H}_{2} \mathrm{~S}$ gas and/or $\mathrm{CH}_{4}$ gas through groundwater with the exchange of hydrogen isotopes between the gases and water. At the highest $\delta^{2 / 1} \mathrm{H}=-8.3 \%$ o $(\mathrm{C} 5 \mathrm{c})$, using Equations (2) and (3), we obtain: 


$$
{ }^{2 / 1} \delta_{\mathrm{H}_{2} \mathrm{~S}}=\frac{1}{2 / 1 \alpha_{\mathrm{H}_{2} \mathrm{O}-\mathrm{H}_{2} \mathrm{~S}}}\left({ }^{2 / 1} \delta_{\mathrm{H}_{2} \mathrm{O}}+1\right)-1=\frac{1}{2.587}(-0.0085+1)-1=-617 \%
$$

and

$$
{ }^{2 / 1} \delta_{\mathrm{CH}_{4}}=\frac{1}{2 / 1 \alpha_{\mathrm{H}_{2} \mathrm{O}-\mathrm{CH}_{4}}}\left({ }^{2 / 1} \delta_{\mathrm{H}_{2} \mathrm{O}}+1\right)-1=\frac{1}{1.283}(-0.0085+1)-1=-227 \% \text { o. }
$$

At least for $\mathrm{CH}_{4}$, the ${ }^{2 / 1} \delta$ values are, for example, in the range of the values characterising the gases related to oil fields worldwide [96].

Next, we consider a closed system under strongly reducing conditions in which $\mathrm{H}_{2} \mathrm{~S}$ and/or $\mathrm{CH}_{4}$ are produced by reduction at the expense of $\mathrm{S}$ of sulfate and/or of $\mathrm{C}$ of carbonate species in solution

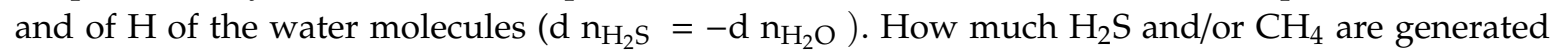
to produce the hydrogen isotope variation observed in the investigated groundwater (i.e., ${ }^{2 / 1} \delta_{\mathrm{H}_{\mathrm{tot}}}$ from $-23.5 \%$ o to $-8.3 \%$ o) ? We consider ${ }^{2 / 1} \delta$ in the water at the beginning of reduction (in our case, ${ }^{2 / 1} \delta_{\mathrm{H}_{\mathrm{tot}}}={ }^{2 / 1} \delta_{\mathrm{H}_{2} \mathrm{O}, \mathrm{o}}=-23.5 \%$, where the subscript, $o$, indicates the initial condition) and at a defined stage of reduction $\left({ }^{2 / 1} \delta_{\mathrm{H}_{2} \mathrm{O}}=-8.3 \%\right.$ o) as well as the value of ${ }^{2 / 1} \alpha_{\mathrm{H}_{2} \mathrm{O}-\mathrm{H}_{2} \mathrm{~S}}$ (liquid water and gaseous hydrogen sulfide). The following equation is easily derived from the isotope balance.

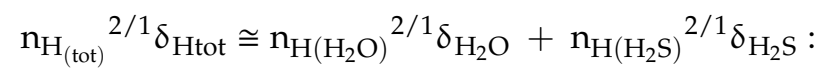

$$
\begin{aligned}
& \frac{\left.\mathrm{n}_{\mathrm{H}\left(\mathrm{H}_{2} \mathrm{~S}\right.}\right)}{\mathrm{n}_{\mathrm{Htot}}}=\frac{\mathrm{n}_{\mathrm{H}_{2} \mathrm{~S}}}{\mathrm{n}_{\mathrm{H}_{2} \mathrm{O}, \mathrm{o}}}=\frac{\left({ }^{2 / 1} \delta_{\mathrm{Htot}}-{ }^{2 / 1} \delta_{\mathrm{H}_{2} \mathrm{O}}\right)}{\left(\frac{{ }^{2 / 1} \delta_{\mathrm{H}_{2} \mathrm{O}}+1}{2 / 1 \alpha_{\mathrm{H}_{2} \mathrm{Ol}}-\mathrm{H}_{2} \mathrm{Sgas}}-1-{ }^{2 / 1} \delta_{\mathrm{H}_{2} \mathrm{O}}\right)} \frac{(-0.0235+0.0085)}{\left(\frac{-0.0085+1}{2.587}-1+0.0085\right)}=0.024,
\end{aligned}
$$

where $\mathrm{n}_{\mathrm{H}\left(\mathrm{H}_{2} \mathrm{~S}\right)}$ and $\mathrm{n}_{\mathrm{Htot}}$ indicate the number of moles of $\mathrm{H}$ in $\mathrm{H}_{2} \mathrm{~S}$ and the total number of moles of $\mathrm{H}$ in $\mathrm{H}_{2} \mathrm{O}$ at the beginning of the process, respectively. This equation may be used to estimate the molar ratio $\mathrm{n}_{\mathrm{H}_{2} \mathrm{~S}} / \mathrm{n}_{\mathrm{H}_{2} \mathrm{O}, \mathrm{o}}$ when is ${ }^{2 / 1} \delta_{\mathrm{H}_{2} \mathrm{O}}=-8.5 \%$ o. For $\mathrm{n}_{\mathrm{H}_{2} \mathrm{O}, \mathrm{o}}=100$, we obtain $\mathrm{n}_{\mathrm{H}_{2} \mathrm{~S}}=100 * 0.024=2.4$ (moles). Although this calculation is only a rough approximation, it indicates that the formation of a few moles of $\mathrm{H}_{2} \mathrm{~S}$ is sufficient to greatly increase the delta values of hydrogen of the groundwater.

Similarly, we write:

$$
\frac{\mathrm{n}_{\mathrm{H}\left(\mathrm{CH}_{4}\right)}}{\mathrm{n}_{\mathrm{Htot}}}=\frac{2 \mathrm{n}_{\mathrm{CH} 4}}{\mathrm{n}_{\mathrm{H} 2 \mathrm{O}, \mathrm{o}}}=\frac{\left({ }^{2 / 1} \delta_{\mathrm{Htot}}-{ }^{2 / 1} \delta_{\mathrm{H}_{2} \mathrm{O}}\right)}{\left(\frac{2 / 1}{{ }^{2 / 1} \alpha_{\mathrm{H}_{2} \mathrm{O}} \mathrm{O}-\mathrm{CH}_{4}}-1-{ }^{2 / 1} \delta_{\mathrm{H}_{2} \mathrm{O}}\right)} \frac{(-0.0235+0.0085)}{\left(\frac{-0.0085+1}{1.283}-1+0.0085\right)}=0.064
$$

In this case, for $\mathrm{n}_{\mathrm{H} 2 \mathrm{O}, \mathrm{o}}=100$, we obtain $\mathrm{n}_{\mathrm{CH} 4}=0.5 * 100 * 0.0636=3.2$ (moles). Thus, a few moles per cent of $\mathrm{CH}_{4}$ formed is sufficient to greatly increase the hydrogen delta values of the groundwater.

It is noteworthy that whereas $\mathrm{CH}_{4}$ gas is only slightly soluble, $\mathrm{H}_{2} \mathrm{~S}$ gas is strongly soluble in water. The weight ratio total S(II-) as $\mathrm{H}_{2} \mathrm{~S}$ to total C(IV-) as $\mathrm{CH}_{4}$ is about $122 \pm 3$ in pure water at the temperature of $21^{\circ} \mathrm{C}$ for partial pressure of these gases ranging from $10^{-4}$ to $3 \mathrm{~atm}$, according to the PHREEQC speciation program [97]; moreover, salinity does not greatly change this result. Already at about $3-4 \mathrm{mg} / \mathrm{L}$ of total $\mathrm{H}_{2} \mathrm{~S}$, the waters typically smell; thus, the absence of a bad smell would indicate that $\mathrm{H}_{2} \mathrm{~S}$ is absent or present in only a small amount that supports a prevalent long-term role of methane seepage or the relevant role of methane generation.

As described in a previous paragraph, there is an evident correlation between $\delta^{2 / 1} \mathrm{H}$ and T.U. Two different explanations can be proposed for this behavior:

(1) The chemical component carrying ${ }^{3} \mathrm{H}$ may also be the cause of increasing $\delta^{2 / 1} \mathrm{H}$. This carrier could be methane formed by degradation of organic matter in an environment where tritium may reach high values, such as sediments rich in organic matter that acquired a high tritium concentration at the time of atomic weapon experiments. For instance, Eyrolle et al. [98] reported high tritium concentrations in the organic portion of the sediments from the Loire River in Western France. 
These findings "demonstrate that tritium from global atmospheric fallout stored in a sedimentary reservoir for decades as organically bound forms". However, the presence of a modern organic substance in deep sediments is impossible in undisturbed settings.

(2) The chemical component carrying ${ }^{3} \mathrm{H}$ may be different from that of increasing $\delta^{2 / 1} \mathrm{H}$. Thus, the two processes are separate but correlated. The enrichment in ${ }^{2} \mathrm{H}$ is caused by exchange with methane, whereas the enrichment in ${ }^{3} \mathrm{H}$ is attributed to more or less prolonged groundwater pathways. In this scenario, the deepest investigated groundwater (higher ${ }^{3} \mathrm{H}$ content in $\mathrm{C} 5 \mathrm{c}$ ) is characterised by a longer residence time and a major link to rainwater precipitated during the 1950s and 1960s. At the same time, a heterogeneous distribution of organic matter and methanogenic archaea within the saturated medium could lead to (i) different amounts of methane and (ii) a more or less prolonged interaction between the gas and groundwater at different depths. Moreover, considering the decrease of hydraulic head with depth and the downward groundwater flow component, the C5a groundwater type (characterised by relatively low $\delta^{2 / 1} \mathrm{H}$ and ${ }^{3} \mathrm{H}$ values) may progressively dilute the deepest $\mathrm{C} 5 \mathrm{c}$ groundwater type, thus causing a mixing between two waters with extreme $\delta^{2 / 1} \mathrm{H}$ and ${ }^{3} \mathrm{H}$ values, namely $\mathrm{C} 5 \mathrm{a}$ and $\mathrm{C} 5 \mathrm{c}$.

With the currently available data, we cannot choose between these hypotheses, but the second one seems the most reasonable. Further research is planned to be carried out to refine knowledge about this issue, including the possibility of finding a similar phenomenon in other portions of the heterogeneous medium.

\section{Concluding Remarks}

The in-depth analysis carried out at the study site made it possible to refine knowledge about the hydrogeological behavior of evaporite-bearing low-permeability successions at a representative site. In more details:

- Hydrogeological investigations and isotopic analyses demonstrated the coexistence of relatively brief to very prolonged groundwater pathways, but everywhere recharged by local precipitation;

- The deuterium content of some samples showed unusual values for groundwater; however, the coupled isotopic-biomolecular approach allowed to demonstrate that these unusual values are due to the interactions between the groundwater and certain gases $\left(\mathrm{H}_{2} \mathrm{~S}\right.$ and $\left.\mathrm{CH}_{4}\right)$, the presences of which are linked to sulfate-reducing bacteria and methanogenic archaea;

- At this stage of the research, these unusual isotopic content was detected in only one sampling sub-area (C5-cluster); nevertheless, this discrepancy between C5-groundwaters and those sampled in the other available wells is not surprising when taking into consideration the (hydro)geological heterogeneity of the investigated system, as well as the results obtained in a similar setting from the biogeochemical points of view [14-16]; in this previous case, a "patchwork" of geochemical and microbiological sub-environments was detected within the whole heterogeneous system, therefore demonstrating the coexistence of different microbial communities (with different microbial activity) also at a metric or decametric scale.

Taking into consideration the interesting results obtained at this stage concerning the heterogeneous distribution of biogeochemical processes, and the importance of moving from speculations to statements concerning the role of $\mathrm{H}_{2} \mathrm{~S} / \mathrm{CH}_{4}$ in influencing the local anomaly in deuterium content, a second step of the research is in progress. During this new phase, the study area will be significantly expanded, and the actual data set will be integrated also with measures of gas concentration and their isotopes, organic carbon percentage in both sediments and groundwater.

In a wider, and methodological context, the present study further demonstrates the importance of interdisciplinary approaches when studying such complex hydrogeological systems. An interdisciplinary approach combining well-established investigation methods (in this case, hydrogeological, isotopic and biomolecular methods), allows refinement of knowledge about the hydrogeological features and behavior of heterogeneous media characterised by evaporite-bearing 
successions, and can help ensure correct interpretation of the meaning of each data type, avoiding misunderstandings and misinterpretations. Thus, this work can be used to refine the guidelines used to study heterogeneous media through purpose-designed interdisciplinary approaches and plan optimal monitoring networks and protocols for several anthropogenic purposes (e.g., environmental monitoring of landfills or contaminated sites).

Author Contributions: Conceptualisation, P.R., C.C., P.I., E.R., A.M.S., F.C.; methodology, P.R., C.C., P.I., E.R., A.M.S., F.C.; investigation, P.R., C.C., G.Z.; data curation, P.R., C.C., G.Z.; writing-original draft preparation, P.R., C.C.; writing-review and editing, P.R., C.C., P.I., E.R., A.M.S., F.C.; visualisation, P.R., C.C., G.Z.; supervision, P.I., E.R., A.M.S., F.C.; project administration, F.C. and E.R.; funding acquisition, F.C. and E.R. All authors have read and agreed to the published version of the manuscript.

Funding: This research was funded by Catanzaro Costruzioni S.r.l. (Heads of Funds: E. Rotigliano, F. Celico).

Acknowledgments: We warmly acknowledge Fabio Catanzaro, Salvatore Accardo and Rosario Varsalona and Giampiero Venturelli for useful discussions. The authors would like to thank anonymous reviewers for their fruitful comments. This work has benefited from the equipment and framework of the COMP-HUB Initiative, funded by the 'Departments of Excellence' program of the Italian Ministry for Education, University and Research (MIUR, 2018-2022).

Conflicts of Interest: The authors declare no conflict of interest.

\section{References}

1. Hsu, K.J.; Ryan, W.B.F.; Cita, M.B. Late miocene desiccation of the Mediterranean. Nature 1973, 242, $240-244$. [CrossRef]

2. Krijgsman, W.; Hilgen, F.J.; Raffi, I.; Sierro, F.J.; Wilson, D.S. Chronology, causes and progression of the Messinian salinity crisis. Nature 1999, 400, 652-655. [CrossRef]

3. Vidal, L.; Bickert, T.; Wefer, G.; Rohl, U. Late Miocene stable isotope stratigraphy of SE Atlantic ODP Site 1085: Relation to Messinian events. Mar. Geol. 2002, 180, 71-85. [CrossRef]

4. Duggen, S.; Hoernie, K.; van Den Bogaard, V.; Rqpke, L.; Morgan, J.P. Deep roots of the Messinian salinity crisis. Nature 2003, 422, 602-606. [CrossRef]

5. Selli, R., II. Messiniano Mayer-Eymar. Proposta di un neostratotipo (The Messinian Mayer-Eymar. A proposal for a neostratotype). G. Geol. 1960, 28, 1-33.

6. Hsü, K.; Montadert, L.; Bernoulli, D.; Cita, M.B.; Erickson, A.; Garrison, R.E.; Kidd, R.B.; Melieres, F.; Muller, C.; Wright, R. History of the Mediterranean salinity crisis. Nature 1977, 267, 399-403. [CrossRef]

7. Butler, R.W.H.; Maniscalco, R.; Sturiale, G.; Grasso, M. Stratigraphic variations control deformation patterns in evaporite basins: Messinian examples, onshore and offshore Sicily (Italy). J. Geol. Soc. Lond. 2015, 172, 113-124. [CrossRef]

8. Balestra, M.; Corrado, S.; Aldega, L.; Gasparo Morticelli, M.; Sulli, A.; Rudkiewicz, J.L.; Sassi, W. Thermal and structural modeling of the Scillato wedge-top basin source-to-sink system: Insights into the Sicilian fold-and-thrust belt evolution (Italy). Geol. Soc. Am. Bull. 2019, 131, 1763-1782. [CrossRef]

9. Gasparo Morticelli, M.; Valenti, V.; Catalano, R.; Sulli, A.; Agate, M.; Avellone, G.; Gugliotta, C. Deep controls on foreland basin system evolution along the sicilian fold and thrust belt. Bull. Soc. Géol. Fr. 2015, 186, 273-290. [CrossRef]

10. Conti, A.; Sacchi, E.; Chiarle, M.; Martinelli, G.; Zuppi, G.M. Geochemistry of the formation waters in the Po plain (Northern Italy): An overview. Appl. Geochem. 2000, 15, 51-65. [CrossRef]

11. Pingue, L.; Marrone, G. Su alcune acque mineralizzate della provincia di Avellino (Some insight on a mineralized water in the Avellino province). Econ. Irp. 1972, 1, 5-16.

12. Di Nocera, S.; Imperato, M.; Matano, F.; Stanzione, D.; Valentino, G.M. Caratteri geologici ed idrogeologici della valle di Ansanto (Irpinia Centrale, Appennino Campano-Lucano) (Geological and hydrogeological features of the Ansanto Valley (Irpinia, Campano-Lucano Appenine). Boll. Soc. Geol. Ital. 1999, 118, 395-406.

13. Ortolani, F.; De Gennaro, M.; Ferreri, M.; Ghiara, M.R.; Stanzione, D.; Zenone, F. Prospettive geotermiche dell'Irpinia centrale (Appennino Meridionale): Studio geologico-strutturale e geochimica (Geothermal perspectives of the central Irpinia (Southern Appenine): Geological, structural ande geochemical studies). Boll. Soc. Geol. Ital. 1981, 100, 139-159. 
14. Celico, F.; Capuano, P.; De Felice, V.; Naclerio, G. Hypersaline groundwater genesis assessment through a multidisciplinary approach: The case of Pozzo del Sale spring (southern Italy). Hydrogeol. J. 2008, 16, 1441-1451. [CrossRef]

15. Boschetti, T.; De Felice, V.; Celico, F. The Pozzo del Sale waters (Irpinia, Southern Apennines, Italy): Chemical-Isotope salt effects and paleoenvironmental implications for Late Messinian evaporates. Aquat. Geochem. 2013, 19, 303-322. [CrossRef]

16. Petrella, E.; Bucci, A.; Ogata, K.; Zanini, A.; Naclerio, G.; Chelli, A.; Francese, R.; Boschetti, T.; Pittalis, D.; Celico, F. Hydrodynamics in evaporate-bearing fine-grained successions investigated through an interdisciplinary approach: A test study in Southern Italy. Geofluids 2018. [CrossRef]

17. Eastoe, C.J.; Long, A.; Knauth, P. Stable chlorine isotopes in the Palo Duro Basin, Texas: Evidence for preservation of Permian evaporate brines. Geochim. Cosmochim. Acta 1999, 63, 1375-1382. [CrossRef]

18. Andreo, B.; Gil-Márquez, J.M.; Mudarra, M.; Linares, L.; Carrasco, F. Hypothesis on the hydrogeological context of wetland areas and springs related to evaporitic karst aquifers (Málaga, Córdoba and Jaén provinces, Southern Spain). Environ. Earth Sci. 2016, 75, 759. [CrossRef]

19. Gil-Màrquez, J.M.; Barberà, J.A.; Andreo, B.; Mudarra, M. Hydrological and geochemical processes constraining groundwater salinity in wetland areas related to evaporitic (karst) systems. A case study from Southern Spain. J. Hydrol. 2017, 544, 538-554. [CrossRef]

20. Lyu, M.; Pang, A.; Yin, L.; Zhang, J.; Huang, T.; Yang, S.; Li, Z.; Wang, X.; Gulbostan, T. The control of groundwater flow systems and geochemical processes on groundwater chemistry: A case study in Wushenzhao Basin, NW China. Water 2019, 11, 790. [CrossRef]

21. Acero, P.; Auqué, L.F.; Galve, J.P.; Gutiérrez, F.; Carbonel, D.; Gimeno, M.J.; Yechieli, Y.; Asta, M.P.; Gómez, J.B. Evaluation of geochemical and hydrogeological processes by geochemical modeling in an area affected by evaporate karstification. J. Hydrol. 2015, 529, 1874-1889. [CrossRef]

22. Chiesi, M.; de Waele, J.; Forti, P. Origin and evolution of a salty gypsum/anhydrite karst spring: The case of Poiano (Northern Apennines, Italy). Hydrogeol. J. 2010, 18, 1111-1124. [CrossRef]

23. Zhu, S.; Zhang, F.; Zhang, Z.; Kung, H.; Yushanjiang, A. Hydrogen and oxygen isotope composition and water quality evaluation for different water bodies in the Ebinur Lake watershed, Northwestern China. Water 2019, 11, 2067. [CrossRef]

24. Porowski, A.; Porowska, D.; Halas, S. Identification of sulfate sources and biogeochemical processes in an aquifer affected by peatland: Insights from monitoring the isotopic composition of groundwater sulfate in Kampinos National Park, Poland. Water 2019, 11, 1388. [CrossRef]

25. Petrella, E.; Celico, F. Mixing of water in a carbonate aquifer, southern Italy, analysed through stable isotope investigations. Int. J. Speleol. 2013, 42, 25-33. [CrossRef]

26. Walker, D.; Parkin, G.; Gowing, J.; Haile, A.T. Development of a Hydrogeological Conceptual Model for Shallow Aquifers in the Data Scarce Upper Blue Nile Basin. Hydrology 2019, 6, 43. [CrossRef]

27. Duckett, K.A.; Langman, J.B.; Bush, J.H.; Brooks, E.S.; Dunlap, P.; Welker, J.M. Isotopic Discrimination of Aquifer Recharge Sources, Subsystem Connectivity and Flow Patterns in the South Fork Palouse River Basin, Idaho and Washington, USA. Hydrology 2019, 6, 15. [CrossRef]

28. Eissa, M.A. Application of Multi-Isotopes and Geochemical Modeling for Delineating Recharge and Salinization Sources in Dahab Basin Aquifers (South Sinai, Egypt). Hydrology 2018, 5, 41. [CrossRef]

29. Clauer, N.; Techer, I.; Chaudhuri, S. Geochemical Tracing of Potential Hydraulic Connections between Groundwater and Run-Off Water in Northeastern Kansas, USA. Hydrology 2017, 4, 56. [CrossRef]

30. Bucci, A.; Petrella, E.; Naclerio, G.; Allocca, V.; Celico, F. Microorganisms as contaminants and natural tracers: A 10-year research in some carbonate aquifers (southern Italy). Environ. Earth Sci. 2015, 74, $173-184$. [CrossRef]

31. Bucci, A.; Petrella, E.; Celico, F.; Hynds, P.D.; Naclerio, G. The use of molecular approaches in hydrogeological studies: Carbonate aquifers in Southern Italy. Hydrogeol. J. 2017, 25, 1017-1031. [CrossRef]

32. Bucci, A.; Petrella, E.; Naclerio, G.; Gambatese, S.; Celico, F. Bacterial migration through low-permeability fault zones in compartmentalised aquifer systems: A case study in Southern Italy. Int. J. Speleol. 2014, 43, 273-281. [CrossRef]

33. Rizzo, P.; Petrella, E.; Bucci, A.; Salvioli Mariani, E.; Chelli, A.; Sanangelantoni, A.M.; Raimondo, M.; Quagliarini, A.; Celico, F. Studying hydraulic interconnections in low-permeability media by using bacterial communities as natural tracers. Water 2020, 12, 1795. [CrossRef] 
34. Bucci, A.; Naclerio, G.; Allocca, V.; Celico, P.; Celico, F. Potential use of microbial community investigations to analyze hydrothermal systems behaviour: The case of Ischia island, southern Italy. Hydrol. Process. 2011, 25, 1866-1873. [CrossRef]

35. Rizzo, P.; Bucci, A.; Sanangelantoni, A.M.; Iacumin, P.; Celico, F. Coupled Microbiological-Isotopic Approach for Studying Hydrodynamics in Deep Reservoirs: The Case of the Val d'Agri Oilfield (Southern Italy). Water 2020, 12, 1483. [CrossRef]

36. Naclerio, G.; Fardella, G.; Marzullo, G.; Celico, F. Filtration of Bacillus subtilis and Bacillus cereus spores in a pyroclastic topsoil, carbonate Apennines, southern Italy. Colloids Surf. B Biointerfaces 2009, 70, $25-28$. [CrossRef] [PubMed]

37. Gugliotta, C.; Gasparo Morticelli, M.; Avellone, G.; Agate, M.; Barchi, M.R.; Albanese, C.; Valenti, V.; Catalano, R. Middle Miocene-Early Pliocene wedge-top basins of North-Western Sicily (Italy). Constraints for the tectonic evolution of a "non-conventional" thrust belt, affected by transpression. J. Geol. Soc. Lond. 2014, 171, 211-226. [CrossRef]

38. Avellone, G.; Barchi, M.R.; Catalano, R.; Gasparo Morticelli, M.; Sulli, A. Interference between shallow and deep-seated structures in the sicilian fold and thrust belt, Italy. J. Geol. Soc. Lond. 2010, 167, 109-126. [CrossRef]

39. de Waele, J.; Piccini, L.; Columbu, A.; Madonia, G.; Vattano, M.; Calligaris, C.; D'Angeli, I.; Parise, M.; Chiesi, M.; Sivelli, M.; et al. Evaporite karst in Italy: A review. Int. J. Speleol. 2017, 46, 137-168. [CrossRef]

40. Caracausi, A.; Sulli, A. Outgassing of mantle volatiles in compressional tectonic regime away from volcanism: The role of continental delamination. Geochem. Geophys. 2019, 20, 2007-2020. [CrossRef]

41. Di Maggio, C.; Madonia, G.; Parise, M.; Vattano, M. Karst of Sicily and its conservation. J. Cave Karst Stud. 2012, 74, 157-172. [CrossRef]

42. Decima, D.; Wezel, F.C. Late Miocene evaporites of the central Sicilian Basin, Italy. Initial Rep. Deep Sea Drill. Proj. 1973, 13, 1234-1241.

43. Roveri, M.; Schreiber, B.C.; Iaccarino, S.M.; Vitale, F.P.; Lugli, S.; Caruso, A.; Lucchi, F.R. Clastic vs. primary precipitated evaporites in the messinian sicilian basins. Ateneo Parm. Acta Nat. 2006, 42, 125-199.

44. Decima, A.; Bommarito, S.; La Rosa, N.; Aiello, R. Foglio 636-Agrigento. Carta Geologica d'Italia Alla Scala 1:50.000; Servizio Geologico d'Italia, Istituto Superiore per la Protezione e la Ricerca Ambientale (ISPRA): Roma, Italy, 1972.

45. Cappadonia, C.; Coratza, P.; Agnesi, V.; Soldati, M. Malta and Sicily joined by geoheritage enhancement and geotourism within the framework of land management and development. Swiss J. Geosci. 2018, 8, 253. [CrossRef]

46. Abiye, T.; Shaduka, I. Radioactive Seepage through Groundwater Flow from the Uranium Mines, Namibia. Hydrology 2017, 4, 11. [CrossRef]

47. International Atomic Energy Agency. Water and Environment News; IAEA: Vienna, Austria, 1998.

48. Milani, C.; Hevia, A.; Foroni, E.; Duranti, S.; Turroni, F.; Lugli, G.A.; Sanchez, B.; Martín, R.; Gueimonde, M.; van Sinderen, D.; et al. Assessing the Fecal Microbiota: An Optimized Ion Torrent 16S rRNA Gene-Based Analysis Protocol. PLoS ONE 2013, 8, e68739. [CrossRef]

49. Fischer, M.A.; Güllert, S.; Neulinger, S.C.; Streit, W.R.; Schmitz, R.A. Evaluation of 16S rRNA gene primer pairs for monitoring microbial community structures showed high reproducibility within and low comparability between datasets generated with multiple archaeal and bacterial primer pairs. Front. Microbiol. 2016, 7, 1297. [CrossRef]

50. Caporaso, J.G.; Kuczynski, J.; Stombaugh, J.; Bittinger, K.; Bushman, F.D.; Costello, E.K.; Fierer, N.; Gonzalez Peña, A.; Goodrich, J.K.; Gordon, J.I.; et al. QIIME allows analysis of high-throughput community sequencing data. Nat. Methods 2010, 7, 335-336. [CrossRef]

51. Callahan, B.J.; McMurdie, P.J.; Rosen, M.J.; Han, A.W.; Johnson, A.J.; Holmes, S.P. DADA2: High-resolution sample inference from Illumina amplicon data. Nat. Methods 2016, 13, 581-583. [CrossRef]

52. Bokulich, N.A.; Kaehler, B.D.; Rideout, J.R.; Dillon, M.; Bolyen, E.; Knight, R.; Huttley, G.A.; Caporaso, G.J. Optimizing taxonomic classification of marker-gene amplicon sequences with QIIME 2's q2-feature-classifier plugin. Microbiome 2018, 6, 90. [CrossRef]

53. Quast, C.; Pruesse, E.; Yilmaz, P.; Gerken, J.; Schweer, T.; Yarza, P.; Peplies, J.; Glöckner, F.O. The SILVA ribosomal RNA gene database project: Improved data processing and web-based tools. Nucleic Acids Res. 2012, 41, 590-596. [CrossRef] [PubMed] 
54. Freeze, R.A.; Witherspoon, P.A. Theoretical analysis of regional groundwater flow: 2. Effect of water-table configuration and subsurface permeability variation. Water Resour. Res. 1967, 3, 623-634. [CrossRef]

55. Grassa, F.; Favara, R.; Valenza, M. Moisture source in the Hyblean Mountains region (South-Eastern Sicily, Italy): Evidence from stable isotopes signature. Appl. Geochem. 2006, 21, 2082-2095. [CrossRef]

56. Liotta, M.; Favara, R.; Valenza, M. Isotopic composition of the precipitations in the Central Mediterranean: Origin marks and orographic precipitation effects. J. Geophys. Res. 2006, 111, D19302. [CrossRef]

57. Liotta, M.; Brusca, L.; Grassa, F.; Inguaggiato, S.; Longo, M.; Madonia, P. Geochemistry of rainfall at Stromboli volcano (Aeolian Islands): Isotopic composition and plume-rain interaction. Geochem. Geophys. Geosyst. 2006, 7, Q07006. [CrossRef]

58. Liotta, M.; Bellissimo, S.; Favara, R.; Valenza, M. Isotopic composition of single rain events in the Central Mediterranean. J. Geophys. Res. 2008, 113, D16304. [CrossRef]

59. Fontana, M.; Grassa, F.; Cusimano, G.; Favara, R.; Hauser, S.; Scaletta, R. Geochemistry and potential use of groundwater in the Rocca Busambra area (Sicily, Italy). Environ. Geol. 2009, 57, 885-898. [CrossRef]

60. Liotta, M.; Grassa, F.; D'Alessandro, W.; Favara, R.; Gagliano, E.; Candela, A.; Pisciotta, C.; Scaletta, R. Isotopic composition of precipitation and groundwater in Sicily, Italy. Appl. Geochem. 2013, 34, 199-206. [CrossRef]

61. Madonia, P.; D'Aleo, R.; Di Maggio, C.; Favara, R.; Hartwig, A. The use of shallow dripwater as an isotopic marker of seepage in karst areas: A comparison between Western Sicily (Italy) and the Harz Mountains (Germany). Appl. Geochem. 2013, 34, 231-239. [CrossRef]

62. Giustini, F.; Brilli, M.; Patera, A. Mapping oxygen stable isotopes of precipitation in Italy. J. Hydrol. Reg. Stud. 2016, 8, 162-181. [CrossRef]

63. Petrella, E.; Celico, F. Heterogeneous aquitard properties in sedimentary successions in the Apennine chain: Case studies in southern Italy. Hydrol. Process. 2009, 23, 3365-3371. [CrossRef]

64. Segadelli, S.; Vescovi, P.; Ogata, K.; Chelli, A.; Zanini, A.; Boschetti, T.; Petrella, E.; Toscani, L.; Gargini, A.; Celico, F. A conceptual hydrogeological model of ophiolitic aquifers (serpentinized peridodite): The test example of Mt. Prinzera (northern Italy). Hydrol. Process. 2017, 31, 1058-1073. [CrossRef]

65. Morgenstern, U.; Stewart, M.K.; Stenger, R. Dating of streamwater using tritium in a post nuclear bomb pulse world: Continuous variation of mean transit time with streamflow. Hydrol. Earth Syst. Sci. 2010, 14, 2289-2301. [CrossRef]

66. Harms, P.A.; Visser, A.; Moran, J.E.; Esser, B.K. Distribution of tritium in precipitation and surface water in California. J. Hydrol. 2016, 534, 63-72. [CrossRef]

67. Fernández-Martínez, J.; Pujalte, M.J.; García-Martínez, J.; Mata, M.; Garay, E.; Rodríguez-Valera, F. Description of Alcanivorax venustensis sp. nov. and reclassification of Fundibacter jadensis DSM 12178T (Bruns and Berthe-Corti 1999) as Alcanivorax jadensis comb. nov., members of the emended genus Alcanivorax. Int. J. Syst. Evol. Micr. 2003, 53, 331-338. [CrossRef]

68. Espinosa, E.; Marco-Noales, E.; Gomez, D.; Lucas-Elío, P.; Ordax, M.; Garcías-Bonet, N.; Sanchez-Amat, A. Taxonomic study of Marinomonas strains isolated from the seagrass Posidonia oceanica, with descriptions of Marinomonas balearica sp. nov. and Marinomonas pollencensis sp. nov. Int. J. Syst. Evol. Microbiol. 2010, 60, 93-98. [CrossRef]

69. Rodriguez-Valera, F.; Ruiz-Berraquero, F.; Ramos-Cormenzana, A. Characteristics of the heterotrophic bacterial populations in hypersaline environments of different salt concentrations. Microb. Ecol. 1981, 7, 235-243. [CrossRef]

70. Pati, A.; Gronow, S.; Lapidus, A.; Copeland, A.; Del Rio, T.G.; Nolan, M.; Chertkov, O. Complete genome sequence of Arcobacter nitrofigilis type strain (CIT). Stand. Genom. Sci. 2010, 2, 300. [CrossRef]

71. Rosenberg, A. Pseudomonas halodurans sp. nov., a halotolerant bacterium. Arch. Microbiol. 1983, 136, 117-123. [CrossRef]

72. Suzuki, D.; Li, Z.; Zhang, C.; Katayama, A. Reclassification of Desulfobacterium anilini as Desulfatglans anilini comb. Nov. within Desulfatiglans gen. nov., and description of a 4-chlorophenol-degrading sulfate-reducing bacterium, Desulfatiglans parachlorophenolica sp. nov. Int. J. Syst. Evol. Microbiol. 2014, 64, 3081-3086. [CrossRef] 
73. Sigalevich, P.; Baev, M.V.; Teske, A.; Cohen, Y. Sulfate reduction and possible aerobic metabolism of the sulfate-reducing bacterium Desulfovibrio oxyclinae in a chemostat coculture with Marinobacter sp. strain MB under exposure to increasing oxygen concentrations. Appl. Environ. Microbiol. 2000, 66, 5013-5018. [CrossRef] [PubMed]

74. Burns, J.L.; DiChristina, T.J. Anaerobic respiration of elemental sulfur and thiosulfate by Shewanella oneidensis MR-1 requires psrA, a homolog of the phsA gene of Salmonella enterica serovar typhimurium LT2. Appl. Environ. Microbiol. 2009, 75, 5209-5217. [CrossRef] [PubMed]

75. Jørgensen, B.B.; Bak, F. Pathways and microbiology of thiosulfate transformations and sulfate reduction in a marine sediment (Kattegat, Denmark). Appl. Environ. Microbiol. 1991, 57, 847-856. [CrossRef] [PubMed]

76. Könneke, M.; Bernhard, A.E.; José, R.; Walker, C.B.; Waterbury, J.B.; Stahl, D.A. Isolation of an autotrophic ammonia-oxidizing marine archaeon. Nature 2005, 437, 543-546. [CrossRef] [PubMed]

77. Schoop, G. Halococcus litoralis, ein obligat halophiler Farbstoffbildner. Dtsch Tierarztl Wochenschr 1935, 43, 817-820.

78. Boone, D.R. Methanobacterium. In Bergey's Manual of Systematics of Archaea and Bacteria; Wiley: Hoboken, NJ, USA, 2015; pp. 1-8.

79. Sprenger, W.W.; van Belzen, M.C.; Rosenberg, J.; Hackstein, J.H.; Keltjens, J.T. Methanomicrococcus blatticola gen. nov., sp. nov., a methanol-and methylamine-reducing methanogen from the hindgut of the cockroach Periplaneta americana. Int. J. Syst. Evol. Microbiol. 2000, 50, 1989-1999. [CrossRef]

80. Holt, J.G.; Krieg, N.R.; Sneath, P.H.A.; Staley, J.T. Bergey's Manual of Determinative Bacteriology; William and Wilkins Company: Baltimore, MD, USA, 1994; p. 724.

81. Freeze, R.A.; Cherry, J.A. Groundwater; Prentice-Hall: Englewood Cliffs, NJ, USA, 1979; p. 604. ISBN 978-01-3365-312-0.

82. Drogue, C. Structure de certains aquifers karstiques d'apres les resultants de traveaux de forage. CR Acad. Sci. Paris 1974, 278, 2621-2624.

83. Prtoljan, B.; Kapelj, S.; Dukaric, F.; Vlahovic, I.; Mrinjek, E. Hydrochemical and isotopic evidences for definition of tectonically controlled catchment areas of the Konovle area spring (SE Dalmatia, Croatia). J. Geochem. Explor. 2012, 112, 285-296. [CrossRef]

84. La Vigna, F.; Mazza, R.; Capelli, G. Detecting the flow relationships between deep and shallow aquifers in an exploited groundwater system, using long-term monitoring data and quantitative hydrogeology: The Acque Albule basin case (Rome, Italy). Hydrol. Process. 2013, 27, 3159-3173. [CrossRef]

85. Agosta, F.; Prasad, M.; Aydin, A. Physical properties of carbonate fault rocks, Fucino basin (Central Italy): Implications for fault seal in platform carbonates. Geofluids 2007, 7, 19-32. [CrossRef]

86. Petrella, E.; Aquino, D.; Fiorillo, F.; Celico, F. The effect of low-permeability fault zones on groundwater flow in a compartmentalized system. Experimental evidence from a carbonate aquifer (Southern Italy). Hydrol. Process. 2015, 29, 1577-1587. [CrossRef]

87. Hernandez-Diaz, R.; Petrella, E.; Bucci, A.; Naclerio, G.; Feo, A.; Sferra, G.; Chelli, A.; Zanini, A.; Gonzales-Hernandez, P.; Celico, F. Integrating hydrogeological and microbiological data and modelling to characterize the hydraulic features and behavior of coastal carbonate aquifers: A case in Western Cuba. Water 2019, 11, 1989. [CrossRef]

88. Mangin, A. Contribution à L'étude Hydrodynamique des Aquiferes Karstiques. Ph.D. Thesis, University de Dijon, Dijon, France, 1975.

89. Mangin, A. Karst hydrogeology. In Groundwater Ecology; Gibert, J., Danielopol, D.L., Stanford, J.A., Eds.; Academic Press: San Diego, CA, USA, 1994; pp. 43-67.

90. Segadelli, S.; Vescovi, P.; Chelli, A.; Petrella, E.; De Nardo, M.T.; Gargini, A.; Celico, F. Hydrogeological mapping of heterogeneous, multi-layered ophiolitic aquifers: The test example of Mt. Prinzera (northern Apennines, Italy). J. Maps 2017, 13, 737-746. [CrossRef]

91. Horita, J.; Wesolowski, D.J. Liquid-vapor fractionation of oxygen and hydrogen isotopes of water from the freezing to the critical temperature. Geochim. Cosmochim. Acta 1994, 58, 3425-3437. [CrossRef]

92. Galley, M.R.; Miller, A.I.; Atherly, J.F.; Mohn, M. GS process-physical properties: Chalk River, Ontario, Canada, Atomic Energy of Canada Limited, AECL-4225. In Environmental Isotopes in Hydrogeology; Clark, I., Fritz, P., Eds.; Lewis Publisher: Boca Reton, FL, USA, 1972.

93. Horibe, Y.; Craig, H. D/H fractionation in the system methane-hydrogen-water. Geochim. Cosmochim. Acta 1995, 59, 5209-5217. [CrossRef] 
94. Meister, P.; Liu, B.; Ferdelman, T.G.; Jørgensen, B.B.; Khalili, A. Control of sulphate and methane distributions in marine sediments by organic matter reactivity. Geochim. Cosmochim. Acta 2013, 104, 183-193. [CrossRef]

95. Peketi, A.; Mazumdar, A.; Spk, P. Influence of dual sulfate reduction pathways on pore-fluid chemistry and occurrences of methane hydrate in sediment cores (IODP-353) off Mahanadi basin, Bay of Bengal. Geochem. J. 2020, 54, 1-11. [CrossRef]

96. Liu, Q.; Wu, X.; Wang, X.; Jin, Z.; Zhu, D.; Meng, Q.; Huang, S.; Liu, J.; Fu, Q. Carbon and hydrogen isotopes of methane, ethane, and propane: A review of genetic identification of natural gas. Earth-Sci. Rev. 2019, 190, 247-272. [CrossRef]

97. Parkhurst, D.L.; Appelo, C.A.J. Description of Input and Examples for PHREEQC Version 3-A Computer Program for Speciation, Batch-Reaction, One-Dimensional Transport, and Inverse Geochemical Calculations. In Geological Survey Techniques and Methods; U.S. Department of the Interior; U.S. Geological Survey: Denver, CO, USA, 2013; Book 6, Chapter A43. Available online: https://pubs.usgs.gov/tm/06/a43/ (accessed on 1 July 2020).

98. Eyrolle, F.; Copard, Y.; Lepage, H.; Ducros, L.; Morereau, A.; Grosbois, C.; Cossonnet, C.; Gurriaran, R.; Booth, S.; Desmet, M. Evidence for tritium persistence as organically bound forms in river sediments since the past nuclear weapon tests. Sci. Rep. 2009, 9, 11487. [CrossRef]

Publisher's Note: MDPI stays neutral with regard to jurisdictional claims in published maps and institutional affiliations.

(C) 2020 by the authors. Licensee MDPI, Basel, Switzerland. This article is an open access article distributed under the terms and conditions of the Creative Commons Attribution (CC BY) license (http://creativecommons.org/licenses/by/4.0/). 